\title{
Spraying of dsRNA molecules derived from Phytophthora infestans, as an effective plant protection strategies for the management of potato late blight
}

Sundaresha, $\mathrm{S}^{1 *}$, Sanjeev Sharma ${ }^{1}{ }^{2}$, Aarti Bairwa ${ }^{1}$, Maharishi Tomar 1, Ravinder Kumar ${ }^{1}$, Vinay Bhardwaj $^{1}$, A. Jeevalatha ${ }^{1,3}$, Rahul Bakade ${ }^{1}$, Neha Salaria ${ }^{1}$, Kajal Thakur ${ }^{1}$, Bir Pal Singh ${ }^{1}$ and Chakrabarti, S.K $\mathrm{K}^{1}$

${ }^{1}$ ICAR-Central Potato Research Institute, Shimla-171001. H.P. India.

${ }^{2}$ ICAR-Indian Grassland and Fodder Research Institute, Jhansi-284003 UP. India

${ }^{3}$ ICAR-Indian Institute of Spice Research, Kozhikode-673012, Kerala. India.

*Corresponding Author: sundareshas8@gmail.com

\begin{abstract}
Phytophthora. infestans is a well known late blight causing oomycetes pathogen. It evolves and adapts to the host background and new fungicide molecules rapidly within a few years of their release, may be due to the predominance of transposable elements in its genome. Frequent and huge applications of fungicides cause environmental concerns. Here we developed target specific RNA interference based molecules, that are capable of effectively reducing the late blight infection. cDNA microarray expression data was used for the selection of genes involved in the early stage of infection process, sporulation etc. The in vitro synthesis of double stranded RNA molecule, targeting SDH, EF-1 $\alpha$, GPI-HAM344, PLD-3 and HSP-90 encoding genes revealed the reduction in growth, sporulation and symptom expression, which were subsequently assessed by culture bioassay, detached leaf assay and topical application methods. The multiple genes targeted dsRNA nano clay sprayed plants showed enhanced disease resistance (4\% disease severity) and least sporulation $\left(<1 \times 10^{3}\right)$, compared to naked dsRNA spray. Use of nano clay was assumed to be involved in the effective delivery, protection and boosting the action of RNAi in potato plants. A significant difference in the growth, sporulation count, disease severity and reduced expression of the genes and confocal microscopy imaging authenticates the effects of SIGS on late blight disease progression. Our research demonstrated that topical dsRNA nano clay spray under the open-air environment could be an alternative to chemical fungicides and transgenic approaches as a novel plant protection strategy for late blight in an environmentally friendly manner.
\end{abstract}

Key Words: Double stranded RNA, Nano clay, Phytophthora infestans, Potato, Spray Induced gene silencing (SIGS)

\section{Introduction}

Potato is the principal non grain food crop and is the fundamental staple food for many countries around the world. It has the potential to meet the increasing food demand of fast-growing human population, therefore, it is prescribed under food security mission as the food of the future for the world, where land and water sources are scarce. Healthy disease free seed material and high productivity are the major concerns for sustainable potato based crop systems. Since the incidence of the Irish famine in 1845-1849 caused by late blight, potato production is still adversely affected by this disease [1,2]. Late blight is caused by an oomycete pathogen Phytopthora infestans [3]. It 
completely infects and destroys the plant including stems, leaves, fruits, tubers eventually causing tissue necrosis [4]. This disease seriously affects the temperate highlands and plateau regions than the Indo-Gangetic plains with an average loss in potato crop production by $15 \%$, which amounts to 6.7 million metric tonne potatoes. In spite of the currently existing integrated disease management strategies (disease forecasting, fungicide spray schedules and deployment of resistant varieties) used to effectively manage this disease, its control is still a challenge to the potato growers and breeders. The reason for its inefficient management is its ability to rapidly adapt and evolve with respect to host background within a few years of the release of new resistant varieties $[5]$.

Unlike other oomycete pathogens, the genome of $P$. infestans is $\sim 240$ megabases long, which is definitely the most complex and largest in chromalveolates [6]. Its repetitive DNA accounts for about $74 \%$ of the genome. A number of rapidly evolving effector genes are confined to a number of highly expanding and dynamic regions of the genome. This has a critical function in the quick adaptability of the pathogen according to the host, underpinning the feasibility of its evolution. Currently, a majority of potato growers still practice a regular and repeated application of fungicides and consider it as the most effective disease controlling method. Frequent and unrestrained application of fungicides adversely affects the environment and instigates the evolution of fungicide resistant strains.

Advances in biotechnology and RNA functional biology creates new avenues for the development of novel technologies in the field of agriculture for disease management. The role of double-strand RNA (dsRNA) in RNA interference has triggered the use of RNA molecules as a tool for sequence specific suppression of gene of interest. RNA interference (RNAi) is an evolutionarily conserved and universal gene regulation mechanism in eukaryotes that invokes sequence-specific RNA degradation. Host-induced gene silencing (HIGS) has proved effective against many fungal pathogen interactions, exceptionally in Zymonoseptoria tritici-wheat interaction, which has been proved that, lack of evidence for RNAi activity in the fungus [7]. With the evidence of silencing studies in P.infestans [8-11], advances in HIGS studies strongly showed that RNAi cross kingdom activity in oomycetes fungus Hyalonospora arabidopsidis in Arabidodpsis [12-13]. In HIGS, siRNAs homologous to target fungal gene are produced in the host plant and further silence their target pathogen genes during infection [14]. The HIGS has proved effective in various plant pathogen interaction system including Blumeria and Puccinia in wheat [14-15], Fusarium sp in Barley [16-17], Verticillium in tomato and Arabidopsis [18], Magnoporthae oryaze in rice [19], Aspergiullus flavus in maize [20]. Our previous work proves that transgene mediated silencing of P.infestans Avr $3 a$ gene effectively delays the infection and pathogenesis in potato [11] and the silencing of host susceptible gene has been well demonstrated in potato which showed the inhibition of P.infestans colonisation [21]. RNAi technology is now being used for the external application of RNA molecule to target pathogen specific genes for reducing the inoculum load and resistance development and it has been successfully demonstrated in important fungal pathogens. This external application of small RNAs is termed as spray-induced gene silencing (SIGS). A number of researchers have shown potentiality of in vitro synthesised dsRNA on a number of plant pathogens and their effective movement between plant and pathogen [22-24].

We developed dsRNA spray formulations targeting partial sequences of Sorbitol dehydrogenase (SDH), Translation elongation factor 1- $\alpha$ (EF-1 $\alpha)$, Phospholipase-D like 3 (PLD3), Glycosylphosphatidylinositol-anchored acidic serine-threonine rich HAM34-like protein (GPI- 
HAM34) and Heat shock protein-90 (Hsp90) of the pathogen. SDH is encoded by a group of genes that are induced by starvation and sporulation. These enzymes are associated with the maintenance of osmotic balance and quenching of reactive oxygen [25]. EF-1 $\alpha$ is a fundamental component of the protein synthetic machinery of all archebacteria and eukaryotes. It recruits aminoacyl-tRNA to A-site of $80 \mathrm{~S}$ ribosome, thus initiating the protein translation [26]. The transition from zoospores to cysts is an intricately controlled process and critical step in the pathogen infection cycle. These cysts attach to the leaf surface and initiate the infection cycle. PLD-3 encodes a Phospholipase D (PLD) that hydrolyzes phosphatidylcholine to produce phosphatidic acid (PA), a chief signal molecule and induces of encystment and infection [27].

Based on the earlier RNAi experiments [11] and hypothesis of apoplastic and symplastic movement of RNA molecule, and the dsRNA carrier strategies in plant virus management [23a,b], we have been conducted culture bioassay, detached leaf assay (apoplastic movement) and whole plant spraying of dsRNA (symplastic movement) of the aforementioned five genes against P.infestans in potato. In vitro assay of dsRNA encoding single gene and multiple gene treatment, revealed the significant difference in late blight development. For effective delivery and to maintain the efficacy of the trait, commercially available kaolinite nano clay was used to enhance the RNAi effect on sporulation and disease progression. Inhibition of the expression of targeted genes was effective in arresting life cycle and protecting potato foliage from late blight symptoms. The present study demonstrates the practicality of using dsRNA with an effective nano clay mediated delivery system, for the management of potato late blight. In future, the utility and versatility of dsRNA molecules could turn into new plant protection strategy as viable nextgeneration fungicides/biomolecule for food safety and agricultural production in an environmentally friendly and sustainable manner.

\section{Materials and methods}

\subsection{Culturing pathogen and isolation of RNA from mycelia, sporangia and zoospore}

P. infestans isolate HP10-45 (A2 mating type) was grown at $18^{\circ} \mathrm{C}$ in the dark on rye agar medium supplemented with 2\% sucrose [28]. Mycelium, to be used for isolation of RNA, were grown in a liquid rye sucrose medium at $18^{\circ} \mathrm{C}$. Mycelia were harvested by centrifugation (Sigma, USA) of the liquid medium at $5000 \times \mathrm{g}$ for $5 \mathrm{~min}$, snap frozen in liquid nitrogen, and total RNA extracted using MN Plant RNA kit and protocol were followed according to manufactures instructions. Sporangium was isolated by using 10-day old culture and flooded with water and rubbed a glass rod to generate sporangial suspension and the filtered through $50 \mu \mathrm{m}$ nylon mesh to remove hyphal fragments. Zoospores were obtained by placing a sporangial suspension at $4{ }^{\circ} \mathrm{C}$ for 15 minutes. Sign of sporangial cleavage was visible in a small amount and swimming zoospores were isolated by passage through $10 \mu \mathrm{m}$ mesh to remove un germinated sporangia and pelleting at 5,000 $\times \mathrm{g}$ for 5 min. Sporangial and zoospores RNA was isolated by using NucleoSpin Plant RNA kit (Machery Nagel, Germany) according to manufactures instructions.

Total RNA was reverse transcribed into double-stranded cDNA by using the cDNA synthesis system (Roche). The cDNA was further labelled with $\mathrm{Cy} 3$ before hybridization using One-Color DNA labelling Kit (Roche, NimbleGen) following the manufacturer's instructions. Other steps like $\mathrm{Cy} 3$ probe labelling, hybridisation, washing, drying and scanning were processed 
by following the instructions described as in Nimble Gen MS 200 Microarray Scanner Operator's Manual v1.0.

\subsection{Oligonucleotide microarray construction}

The $P$. infestans genome sequence available at Broad institute technology MIT, USA website (http://www.broad. mit.edu/annotation/genome/phytophthora_infestans/Home. html) was used to construct 60 mer oligonucleotide microarray chips by Roche NimbleGen Inc., Madison, USA using a multi-step approach to select probes with optimal predicted hybridization characteristics. Three oligonucleotide probes were selected per Uni Gene, comprising a probe set, and each probe set is represented on the final array by two replicates. The arrays were of $12 \times 135 \mathrm{~K}$ format, which contained 12 arrays on a single slide $(25 \mathrm{~mm} \times 76 \mathrm{~mm})$ and each array with 1,35,000 probe features targeting 18,043 genes.

\subsection{Microarray data analysis}

Microarray expression data were extracted from the scanned images of the arrays. Image analysis and signal quantification were performed with Nimble Scan software v 1.0. Robust multi-array analysis was performed using the software involving background adjustment, quantile normalization, and median polish summarization as described by Irizarry et al. [29a,b]. Probe set data, with normalized expression values in RMA call files, were imported to Array star software version 4.0.2 and statistical analysis was performed. The data were analysed individually for each comparison using the log (base 2) transformed normalized expression values as input data. Statistical filtering of data was performed by calculating student $t$-test value for each comparison and $p$ values were adjusted by Benjamin Hochberg false discovery rate correction. The genes were considered up- or down-regulated if fold change at log (base 2) was more than 2 in either of the experiment and $p$-value less than or equal to the level of significance $\alpha=0.05$.

\subsection{Selection of target genes for dsR $\mathrm{N}$ A experiment}

Targets for dsRNA were identified from a list of differentially upregulated genes between mycelium v/s sporangium, Mycelium v/s zoospores and unique genes expression between different stage of pathogen and gene expressed in Kufri Bahar susceptible potato at 24 hpi. Venn diagram and cluster gram analysis showed the expression of 116 unique genes ( $>9$ fold expression) at different stages of the pathogen. These genes were unique to mycelium, sporangium, zoospores and $24 \mathrm{hr}$ challenge inoculated Kufri Bahar leaf sample. Targets genes were selected based on their functional redundancy, and highly regulated genes in all the stages of the pathogen (mycelium, sporangia and zoospores) including during $24 \mathrm{hpi}$ of the pathogen in susceptible potato cultivar sample. List of genes are summarised in Table 1.

\subsection{Development of dsR $\mathrm{NA}$ construct: In-vitro and In vivo synthesis of dsR $\mathrm{A} A$}

The total RNA was isolated from infested potato plants and also from fungal mycelium using Plant RNA easy kit (MN, Germany) and concentration of the extract was quantified spectrophotometrically (UV- Vis, Shimadzu Corporation, Japan) at $260 \mathrm{~nm}$. One microgram of total RNA was subjected to cDNA synthesis using AMV reverse transcriptase enzyme (High capacity 
reverse transcriptase cDNA synthesis kit, Applied Biosystem USA). Reverse transcriptase PCR was performed to isolate the $P$. infestans Hsp90, EF-1 $\alpha$, SDH, PLD-3 and GPI-HAM34 encoding genes. All three ORF genes were subjected to siRNA target finder tools, siRNA scan software was used to identify the possible off-target sequences and the segment of the gene that was devoid of nonspecificity was used to synthesis the dsRNA. Designed the primer to that specific segment of the gene flanked with T7 promoter sequence. The PCR reaction was carried out, the reaction mixture containing $100 \mathrm{ng}$ of cDNA, 5 picomoles of primer, $25 \mathrm{mM}$ dNTP's mixture, 1 unit of Taq polymerase and $1 \mathrm{x}$ of Taq buffer were kept at a specific annealing temperature of the gene-specific primer (Hsp90, EF-1 $\alpha$, SDH, PLD-3 and GPI-HAM34 encoding genes). Amplified desired fragments were cloned into T/A cloning vector. The positive clones were confirmed through restriction digestion and cycling sequencing method.

For the synthesis of dsRNA, Ambion dsRNA MEGA script ${ }^{\circledR}$ RNAi Kit was used (Invitrogen Pvt. Ltd, USA). It is a system for the preparation of double-stranded RNA (dsRNA), free of protein and other contaminating molecules, for use in RNA interference (RNAi) experiments. The procedure begins with a high yield transcription reaction to synthesize two complementary RNA transcripts from the PCR product amplified from the plasmid template using T7 primers and synthesise dsRNA using T7 polymerase enzyme. The RNA strands are hybridized either during or after the transcription reaction (incubation for $37^{\circ} \mathrm{C}$ for $16 \mathrm{hr}$ ) to form dsRNA. Next, DNA and any single-stranded RNA (ssRNA) are removed with DNAse/RNAse nuclease digestion. Finally, the dsRNA is purified with a solid-phase adsorption system to remove protein as well as mono and oligonucleotides.

\subsection{In vivo and large scale synthesis of dsRNA for topical application}

For multi-gene targets, choose effective siRNA region from each targeted gene sequences, using siRNA target finder tools (http://sidirect2.rnai.jp/; http://bioinfo2.noble.org/RNAiScan.htm). Assembled the selected siRNAs and customise the multi siRNA sequences in a cloning vector (Eurofins Pvt. Ltd). Positive clones carrying multigene siRNA construct can subclone into L4404 vector (harbouring T7 promoter on either side of the polylinker site) at the specific NotI and XhoI restriction enzyme sites. Ligated products are transferred into DH5 $\alpha$ E.coli cells using standard $\mathrm{CaCl}_{2}$ transformation method using LB medium containing $100 \mu \mathrm{g}$ of ampicillin per $\mathrm{ml}$ of LB medium. The positive plasmid clones were confirmed by restriction digestion and subjected to large scale synthesis of dsRNA using T7 Express cells for topical application.

The above multi dsRNA construct, plasmid is transformed into T7 express cells HTT1B, (DE3 Strain) using standard $\mathrm{CaCl}_{2}$ transformation method. Inoculate the $\mathrm{T} 7$ expressing cells carrying multi dsRNA constructs into $1 \mathrm{lt}$ LB medium containing $100 \mu \mathrm{g}$ of Ampicillin/ml of LB medium and incubated with shaking at $37^{\circ} \mathrm{C}$. Induce the cell culture by the addition of IPTG with the final concentration of $0.4 \mathrm{mM}$ and incubate with a shaker at $37^{\circ} \mathrm{C}$ for $3 \mathrm{hr}$.

Centrifuge the culture at $8000 \times g 20 \mathrm{~min}$. Resuspend the pellet into $1 / 50$ vol of $25 \mathrm{mM}$ Tris, $\mathrm{pH}$ 7.5. Lyse the cell with lysis buffer and mix with sonified nano clay solution along with $2 \%$ Tween 20 for topical high pressure spray. To estimate the amount of dsRNA produced, lyse $100 \mu 1$ of the culture by adding $1 \mathrm{M}$ ammonium acetate, chloroform-isoamylalcohol (24:1) and incubate at 65

${ }^{\circ} \mathrm{C}$. Centrifuge and collect the supernatant and precipitate the nucleic acids by adding ethanol and 
incubate at $-80{ }^{\circ} \mathrm{C}$ for at least $15 \mathrm{~min}$. Resuspend the pellet in $10 \mathrm{mM}$ Tris, $\mathrm{pH} 7.5$. Analyze by electrophoresis in $1 \%$ agarose (TBE buffer) and stain with EtBr.

\subsection{Plant material and bioassay}

Late blight susceptible potato cultivars Kufri Bahar and Kufri Jyoti were used for bioefficacy of the dsRNA molecule. The plants were maintained under controlled conditions for the whole plant assay, plants were first grown for 45 days in a greenhouse maintaining the 16 hour light and 8hour dark conditions with the temperature of $18{ }^{\circ} \mathrm{C} / 20^{\circ} \mathrm{C}$ temperature (night/day) conditions and then transferred to a Phytophthora inoculation chamber maintaining $18-20{ }^{\circ} \mathrm{C}$ temperature and $85-90 \%$ relative humidity. The inoculum was prepared from 7 day-old cultures grown on rye agar medium in the dark $\left(18 \pm 1^{\circ} \mathrm{C}\right)$. P. infestans mycelia were harvested in sterile water and stimulated to release zoospores at $4{ }^{\circ} \mathrm{C}$. The sporangia suspension was observed under a hemocytometer and the concentration adjusted to $4 \times 10^{4} / \mathrm{ml}$ for use as an inoculum. The plants were inoculated and the percentage of infection recorded and scored, in accordance to Malcolmson [30]. Leaf samples were collected at $24-\mathrm{h}$ intervals, snap frozen, and stored at $-20{ }^{\circ} \mathrm{C}$ until required. The number of sporangia produced on each lesion was determined from massive sporulated leaf samples of dsRNA treated and non-treated plants using a hemocytometer.

\subsection{Culture bioassay of dsR A}

The required concentration of dsRNA was placed on Rye Agar medium in the centres of the plate, subsequently placed healthy grown P.infestans mycelium bit upside down on the drop of dsRNA such a way that mycelium should contact with dsRNA using a sterile cork borer. Plates were incubated under $18{ }^{\circ} \mathrm{C}$ for 10 days to observe the growth of mycelium in both dsRNA and sterile water plated medium.

\subsection{Detached leaf assay}

The different concentration of dsRNA (100 ng, $150 \mathrm{ng}, 250 \mathrm{ng}$ and $500 \mathrm{ng}$ and 1 microgram of dsRNA concentration) was used to evaluate the late blight symptoms development by employing detached leaf assay. The fourth leaf from the 30 days old potato plants was plucked from potato cultivar Kufri Bahar and leaves were placed abaxial side up, in the plastic trays lined with a wet paper towel (for maintaining humidity, [11] on perforated plastic separators and inoculated with (HP10-45, A2 mating type having 11 virulence genes) zoospore suspension of $4 \times 10^{4}$ sporangial zoospores $/ \mathrm{ml}$. The inoculated leaves were incubated for six days at $18 \pm 1{ }^{\circ} \mathrm{C}$ temperature. Lesion area (LA) was measured daily after determination of the incubation period. Length and breadth of each lesion were recorded and the lesion area was computed by substituting these measurements into the equation for an ellipse as lesion area (LA) $=\pi / 4 * a b$, where, $a=$ length and $b=$ breadth of the lesion [31]. Sporulation (SP) was determined on the $6^{\text {th }}$ day of inoculation. Lesion area $(1 \mathrm{~cm})$ were cut with a sterilized cork borer and transferred to Eppendorf tubes with $5 \mathrm{ml}$ of sterilized distilled water. Tubes were vortex for $20 \mathrm{~s}$ to dislodge sporangia. The plant tissue was removed and sporangia were counted using a haemocytometer. At least two haemocytometer readings were done for each sporangial suspension. 


\subsubsection{Spraying of dsR $A$ molecule with and without nano clay}

For Topical high pressure spray, the positive multi-gene dsRNA clones were transferred into T7 express $E$. coli cells (NEB T7 Express cells, UK) and these cells were induced to synthesize dsRNA using $0.4 \mathrm{mM}$ IPTG for $3 \mathrm{hrs}$. IPTG induced cells were pelleted, lysed with lysis buffer and mixed with $0.5 \%$ nano clay solution. For labelling of T7 cells, during IPTG induction, mixed cy 3 dye and incubated for $3 \mathrm{hrs}$. $P$. infestans zoospore inoculum was prepared $\left(4 \times 10^{4}\right)$ and sprayed on potato plants, 24 hours after spraying of dsRNA-nano clay formulation. For control, we used water and empty $\mathrm{T} 7$ cells also. The plants were kept in late blight screening chamber, maintained at $18^{\circ} \mathrm{C}$ temperature with $90 \% \mathrm{RH}$. Late blight progression was recorded as described earlier. Leaf samples were collected at $24-\mathrm{h}$ intervals, snap-frozen, and stored at $-80^{\circ} \mathrm{C}$ until required. The number of sporangia produced on each lesion was also enumerated using haemocytometer from treated as well as control plants.

\subsubsection{Use of nano clay particle and development of $d s R N A$ formulation}

The nano clay particle (Kaolinite, M/s EICL Pvt. Ltd, Thiruvananthapuram, Kerala, India) at different concentration (5ppm, 10ppm and $20 \mathrm{ppm}$ ) were used to mix with dsRNA. The different concentration of nano clay particles were prepared with nuclease-free water and kept on a magnetic stirrer for overnight. Next day nano solution was kept for sonification for three hours and subsequently mixed with pelleted $0.4 \mathrm{mM}$ IPTG induced T7 cells expressing small RNA harbouring target gene of interest.

\subsubsection{Confocal laser scanning microscopy}

The potato leaf sample and tissues were imaged using an NIKON Plus confocal laser scanning microscopy (Nikon Instruments, USA). The fluorescence of Cy3 in the leaf sample was detected using a $550 \mathrm{~nm}$ laser with a band pass filter of 570nm. Image software was used for image analysis. Fluorescently labelled samples and control samples, treated either with unlabelled dsRNA, were imaged simultaneously using the sample parameters to ensure minimal background fluorescence in the negative control and the positive signals for direct comparison.

\subsubsection{Relative quantification of transcript analysis}

The expression analysis of three fungal genes was performed using qRT-PCR. Gene-specific primers were optimized and used to amplify pathogen Hsp90, EF-1 $\alpha$ and SDH primers and actin A transcripts in RNA recovered from pathogen challenge inoculated and water sprayed plants as control with three biological replications. Expression levels were compared with the transcript levels of a wild-type only zoospores inoculated leaf with calibration sample assigned a relative value of 1.0. Total RNA for qRT-PCR analysis was extracted from frozen samples of individual and multi gene combination dsRNA treated leaves/plants (collected at the end of bioassay i. e. at $6^{\text {th }}$ day after inoculation of the pathogen) using an RNeasy Plant Mini kit (Qiagen, UK), following the manufacturer's protocol. The yield and integrity of RNA were assessed using a NanoDrop Micro Photometer (Thermo Scientific, USA) and agarose gel electrophoresis, respectively. cDNA was synthesized from $1 \mu \mathrm{g}$ of total RNA using a cDNA synthesis kit (Applied Biosystem, USA), following the manufacturer's protocol. For the qRT-PCR, primers designed to amplify the actin A 
gene from $P$. infestans (GenBank accession no. AB061263.1) were used to normalize the data. PCR reactions $(20 \mu \mathrm{L})$ included 20 -ng cDNA, $0.2 \mathrm{mM}$ of each primer, and 10- $\mu \mathrm{L}$ SYBR Premix (Applied Biosystems, USA). Reactions were performed using an ABI PRISM 7300 fast real-time PCR system (Applied Biosystems, USA) under the following conditions: $95{ }^{\circ} \mathrm{C}$ for $30 \mathrm{sec}, 40$ cycles of $95^{\circ} \mathrm{C}$ for $5 \mathrm{sec}$, and $60{ }^{\circ} \mathrm{C}$ for $31 \mathrm{sec}$; followed by $95^{\circ} \mathrm{C}$ for $15 \mathrm{sec}, 60{ }^{\circ} \mathrm{C}$ for $1 \mathrm{~min}$, and $95{ }^{\circ} \mathrm{C}$ for $15 \mathrm{sec}$ to obtain melt curves. The expression of each gene relative to average $\mathrm{Ct}$ values of the housekeeping gene i. e. $P$. infestans actin A gene $(\mathrm{Ct}=\mathrm{Ct}$ target gene average $-\mathrm{Ct}$ endogenous gene average) was determined and analyzed using ABI 7300 System Sequence Detection Software Version 1.4 (Applied Biosystems, USA). Quantification of the relative changes in gene transcript level was performed in accordance with the $2^{-\Delta \Delta \mathrm{Ct}}$ method [32]. For control samples, the mean relative expression level of the assayed gene was assigned a value of 1.0, and the relative expression level of all lines calculated relative to it. Results represent the mean of three biological replicates. Standard deviations were calculated for all lines tested using SDSRQ manager software (Applied Biosystems, USA).

\subsubsection{Northern Assay for bacterially expressed dsR $\mathrm{N}$}

Total RNA was recovered from T7 express E. coli cells using Triazole: chloroform method. Small RNAs from $15-\mu \mathrm{g}$ total RNA samples were separated on $15 \%$ polyacrylamide gels. RNAs were transferred to Hybond-N+ membrane (Amersham Bioscience, USA) using the semi-dry blot method, and the blot hybridized with $\alpha[32 \mathrm{P}]-\mathrm{dCTP}$ labelled probe obtained from PCR amplification of the TEF, HSP90 and Sorbitol gene from plasmid DNA using a random primer DNA labelling kit (Amersham, UK). Hybridization was performed at $65{ }^{\circ} \mathrm{C}$ for $18-20 \mathrm{hr}$. The filter was washed at room temperature in $2 \times \mathrm{SSC}$ and $0.1 \% \mathrm{SDS}$, followed by $1 \times \mathrm{SSC}$ and $0.1 \%$ SDS for 10 min each [33]. An image was obtained and analysed using a phosphorimager (Bio-Rad System, USA).

\section{Results}

\subsection{Transcription profiling: Infection and sporulation stage}

The pathogenic success of $P$. infestans relies on its ability to generate a large number of sporangia, which further releases zoospores that differentiate into cysts, critical for the infection cycle. Microarray analysis using cDNA of mycelia, sporangia and zoospores was performed to decipher these stages at a transcriptome level. Cy3 labelled double-stranded cDNA were denatured and hybridised with 18,034 oligo probes encoding $P$. infestans protein encoding genes in a single 12x135K Nimblegen array slide. The slide was scanned by MS II Nimblegen Microarray scanner and the data was analysed by array star software. Our data revealed that out of 18,034 P. infestans protein encoding genes, 1933 were upregulated by $>2$ fold (Supplementary File. S1) and 43 genes were upregulated at $>10$ fold in sporangia (Supplementary File. S2). 1668 genes were upregulated by 2 fold (Supplementary File. S3 ) and 61 genes were upregulated at 15 fold (Supplementary File. $\mathrm{S} 4)$ in zoospores collected at $4{ }^{\circ} \mathrm{C}$. Indicating that temperature plays an important role in regulating the genes in sporangium $\left(18{ }^{\circ} \mathrm{C}\right)$ and zoospores $\left(4{ }^{\circ} \mathrm{C}\right)$. In order to recognize the common genes that are unique to different stages in $P$. infestans life cycle, Venn diagram and clustergram analysis was performed which showed a $>9$ fold increase in the expression of 116 genes out of 4949 genes (Supplementary Figures 1, 2 and Supplementary File. S5, S6). These genes were unique to mycelium, sporangium and zoospores in $24 \mathrm{hr}$ pathogen challenge inoculated Kufri Bahar (KB) 
leaf samples. Five highly expressed genes were selected from these, targeting the fungal cell biology (Table 1). These genes encoded SDH, EF-1 $\alpha$, PLD-3, GPI-HAM34 and Hsp90. The microarray expression data is provided as supplementary material (Supplimentary Files. S1-S6 ).

\subsection{Selection of off target siRNA}

All 5 ORF genes encoding viz, SDH, EF-1 $\alpha, P L D-3, G P I-H A M 34$ and $H s p 90$ were subjected to siRNA target finder tools (http://sidirect2.rnai.jp/) and siRNA scan software(http://bioinfo2.noble.org/RNAiScan.htm). Fragments of the five genes were selected on the basis of the number of effective siRNAs produced (Supporting sequence S1-S5). Primers specific to the siRNA segment of the gene flanked with T7 promoter sequence were designed (Table 2) and subjected to PCR and the specific fragments were cloned in T/A cloning vector. Positive clones were confirmed through restriction digestion and cycling sequencing method (Supplementary Figure 3a). The results revealed that, a fragment size of $425 \mathrm{bp}$ for Hsp90, $402 \mathrm{bp}$ for EF-1 $\alpha, 456$ bp for SDH, 563 bp for PLD-3 and 423 bp for GPI-HAM34 encoding genes, which confirmed the integration of the gene in vector.

For the synthesis of dsRNA, the positive clone plasmid DNA of all the five genes were purified and subjected to dsRNA synthesis using $2 \mu \mathrm{g}$ PCR product with T7 polymerase enzyme and incubated at $37^{\circ} \mathrm{C}$ overnight (Megascript RNAi kit, Ambion, USA). Synthesis of dsRNA of the target gene fragment was confirmed on the gel by the presence of specific gene fragment size with intense expression in smear background (Supplementary Figure 3b). The multi gene targeted dsRNA construct was also similarly confirmed by using $\mathrm{T} 7$ promoter primers.

\subsection{Bioassay of $d s R N A$}

In order to test the inhibitory effect of dsRNA carrying the pathogen target gene, the plates of freshly grown mycelium were incubated with dsRNA at a concentration of $100 \mathrm{ng}, 150 \mathrm{ng}, 200$ $\mathrm{ng}, 250 \mathrm{ng}$ and $500 \mathrm{ng}$ per microlitre and kept at $18{ }^{\circ} \mathrm{C}$ for 10 days (see material and methods). Results revealed that synergetic RNAi on EF-1 $\alpha$, Hsp90 and SDH encoding genes resulted in the maximum inhibition of mycelium growth at a concentration of $150 \mathrm{ng}$ dsRNA per microlitre (Figure 1a), then individual dsRNA treatments compared to water control. Whereas the dsRNA combination of GPI-HAM34 and PLD-3 encoding genes completely inhibited the mycelium growth at a concentration of $100 \mathrm{ng}$ dsRNA per microlitre, when compared to water control (Figure 1b). The dsRNA concentration at $200 \mathrm{ng}$ to $250 \mathrm{ng}$, did not showed the significant difference in inhibition of growth of the mycelium (data not showed). 

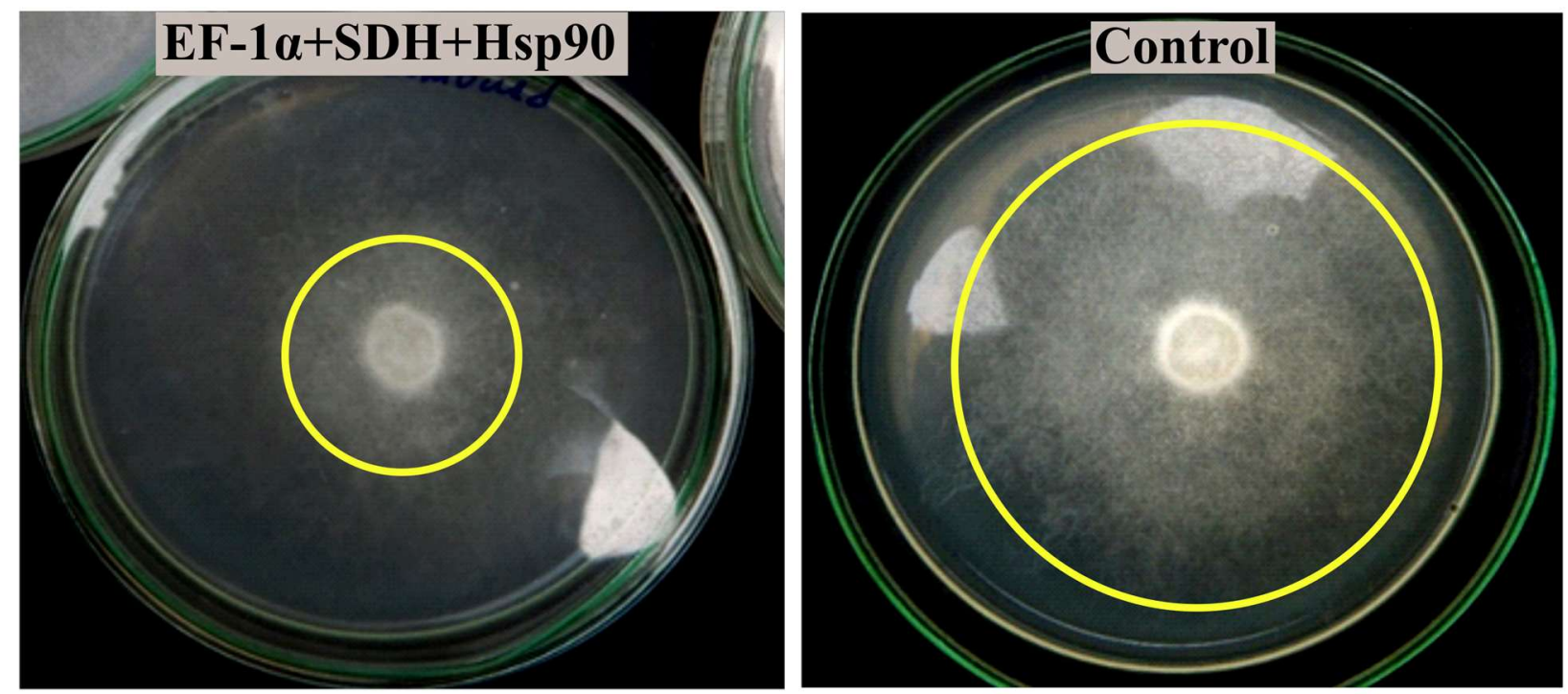

(a)
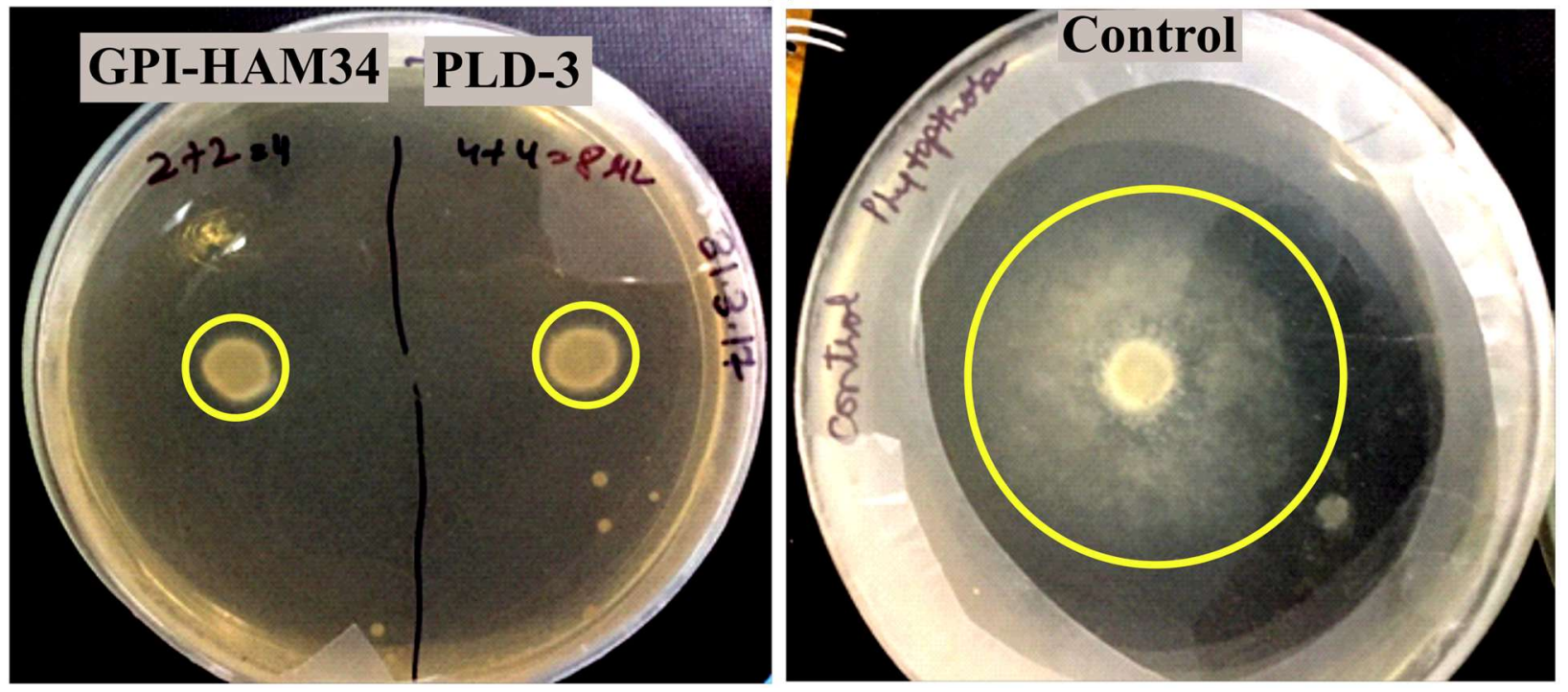

(b)

Figure 1. In vitro culture assay of dsRNA on pathogen growth a) $150 \mathrm{ng} / \mu \mathrm{l}$ dsRNA as a combination of EF-1 $\alpha$, SDH and Hsp90 gene b) $100 \mathrm{ng} / \mu 1$ dsRNA combination of GPIHAM34 and PLD-3 gene.

\subsection{Detached leaf assay of dsRNA (single gene and multi gene targeted long dsR $\mathrm{NA}$ molecule)}

The bioefficacy of all five genes against P.infestans was evaluated using detached leaf assay. Freshly harvested potato single leaves were subjected to a required concentration of dsRNA along with DEPC (Diethyl Pyrocarbonate) treated control and incubated for $24 \mathrm{hr}$ at $18^{\circ} \mathrm{C}$. Subsequently, the pathogen was inoculated $\left(4 \times 10^{4}\right.$ sporangial zoospores $\left./ \mathrm{ml}\right)$ and incubated in a reaction box at $18^{\circ} \mathrm{C}$ with $90 \%$ humidity for five days for the symptom appearance. Results revealed that there was no symptom development on dsRNA treated leaf as compared to the water treated control. Symptoms started appearing on control leaf from the third day after inoculation, but differences between dsRNA treated leaf could be visualised only on the $5^{\text {th }}$ day after inoculation of the pathogen and varied depending upon the gene combination used in the study. Maximum lesion 
area of $7.5 \mathrm{~cm}^{2}$ was observed on water treated control samples while a lesion area of only $1.2 \mathrm{~cm}^{2}$ was observed on the plants subjected to dsRNA harbouring SDH, EF-1 $\alpha$ and Hsp90 encoding genes at a concentration of $250 \mathrm{ng}$ per microlitre. The lesion area varied from $2.3 \mathrm{~cm}^{2}$ to $2.5 \mathrm{~cm}^{2}$ when individual dsRNA (250ng/ul) was applied (Figure 2 and Supplementary Table S1). The other range of dsRNA concentration not showed significant difference. Spore production varied from 2 to $3 \times 10^{3}$ sporangia/ml in leaves individually treated with the dsRNA SDH, EF-1 $\alpha$ and Hsp90 encoding genes Whereas a multi gene targeted dsRNA treatment resulted in spore production of only $1 \times 10^{3}$ sporangia/ml while the untreated control samples produced $7.1 \times 10^{3}$ sporangia/ml (Supplementary Table S1) showing the antisporulating activities of these genes. The combination of dsRNA containing PLD-3 and GPI-HAM34 encoding genes at a concentration of $200 \mathrm{ng} / \mu 1$ resulted in the least lesion area $\left(0.3 \mathrm{~cm}^{2}\right)$ compared to the individual dsRNA application where lesion area ranged from $2.5 \mathrm{~cm}$ to $2.7 \mathrm{~cm}^{2}$ (Figure 3 and Supplementary Table S2). This shows that dsRNA suppresses the progression and development of disease symptoms. The lesion area was categorised into resistant and susceptible as described by Sharma and his group [34].

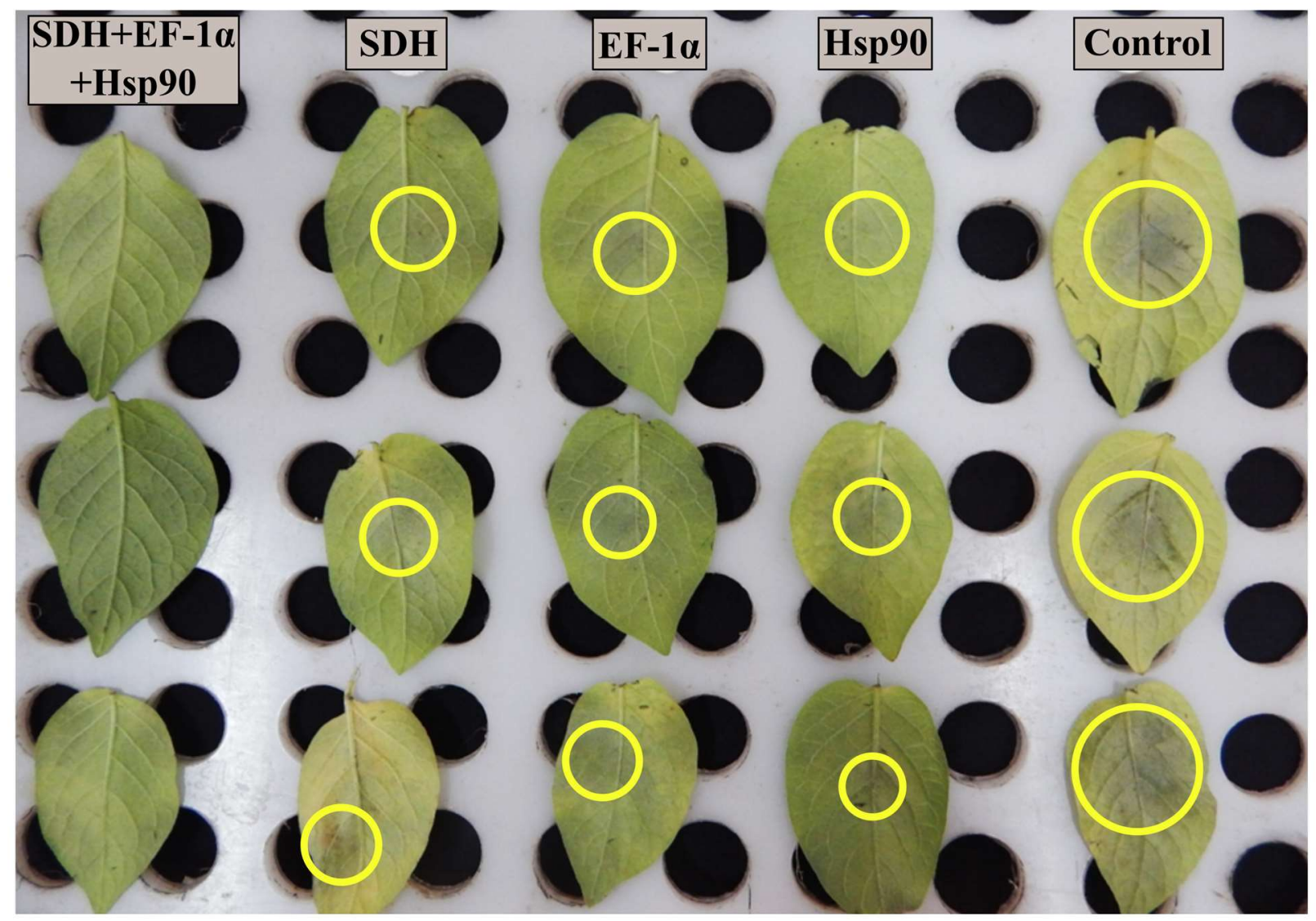

Figure 2. Detached leaf assay of dsRNA encoding SDH, EF-1 $\alpha$ and Hsp90 gene as individually and in combination on late blight symptom development. dsRNA concentration of $250 \mathrm{ng} / \mu \mathrm{l}$ used for each gene. 


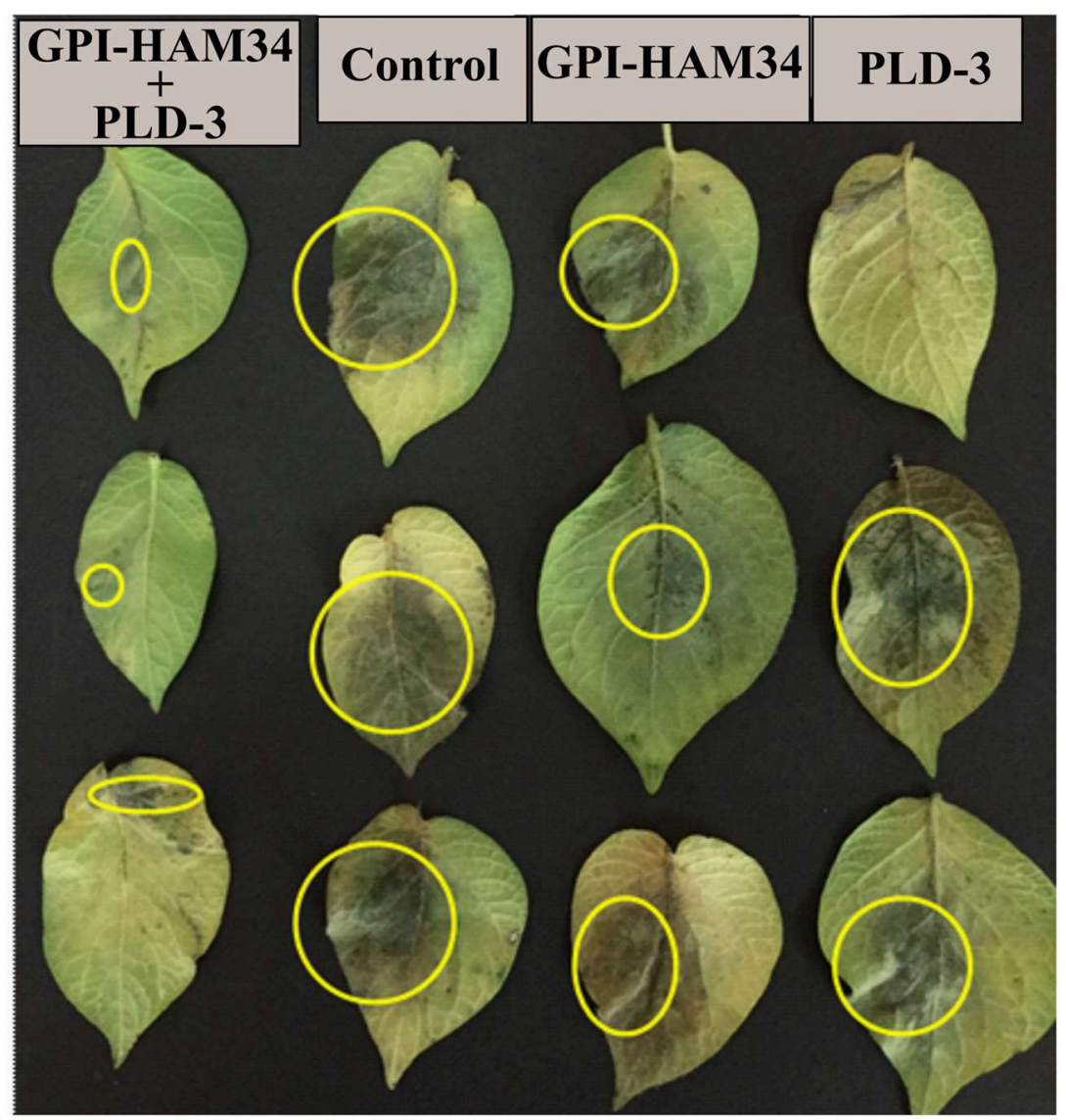

Figure 3. Detached leaf assay of dsRNA encoding GPI-HAM34 and PLD-3 gene as individually and in combination with the concentration of $200 \mathrm{ng} / \mathrm{ul}$ of each

\subsection{Detached leaf assay using dsRNA Nano clay}

In order to effectively deliver the dsRNA into the plant, we amalgamated the dsRNA with nano clay and checked its efficacy using detached leaf assay. The $200 \mathrm{ng} / \mu \mathrm{l}$ of dsRNA with $5 \mathrm{ppm}, 10$ ppm and 20 ppm of nano clay particles have been assessed for disease reaction. Using a detached leaf assay, highly resistant reaction with symptomless lesion area was recorded for $10 \mathrm{ppm}$ nano clay-dsRNA formulation while 5 ppm and 20 ppm-dsRNA formulation exhibited a moderate type of resistant reaction. Control sample leaves containing only nano clay displayed susceptible reaction with lesion area of $5.6 \mathrm{~cm}^{2}$ to $7.8 \mathrm{~cm}^{2}$ (Figure 4, Supplementary Table S2). This confirms the efficacy of dsRNA-nano clay formulations as potential carriers of dsRNA and their use against P.infestans. 

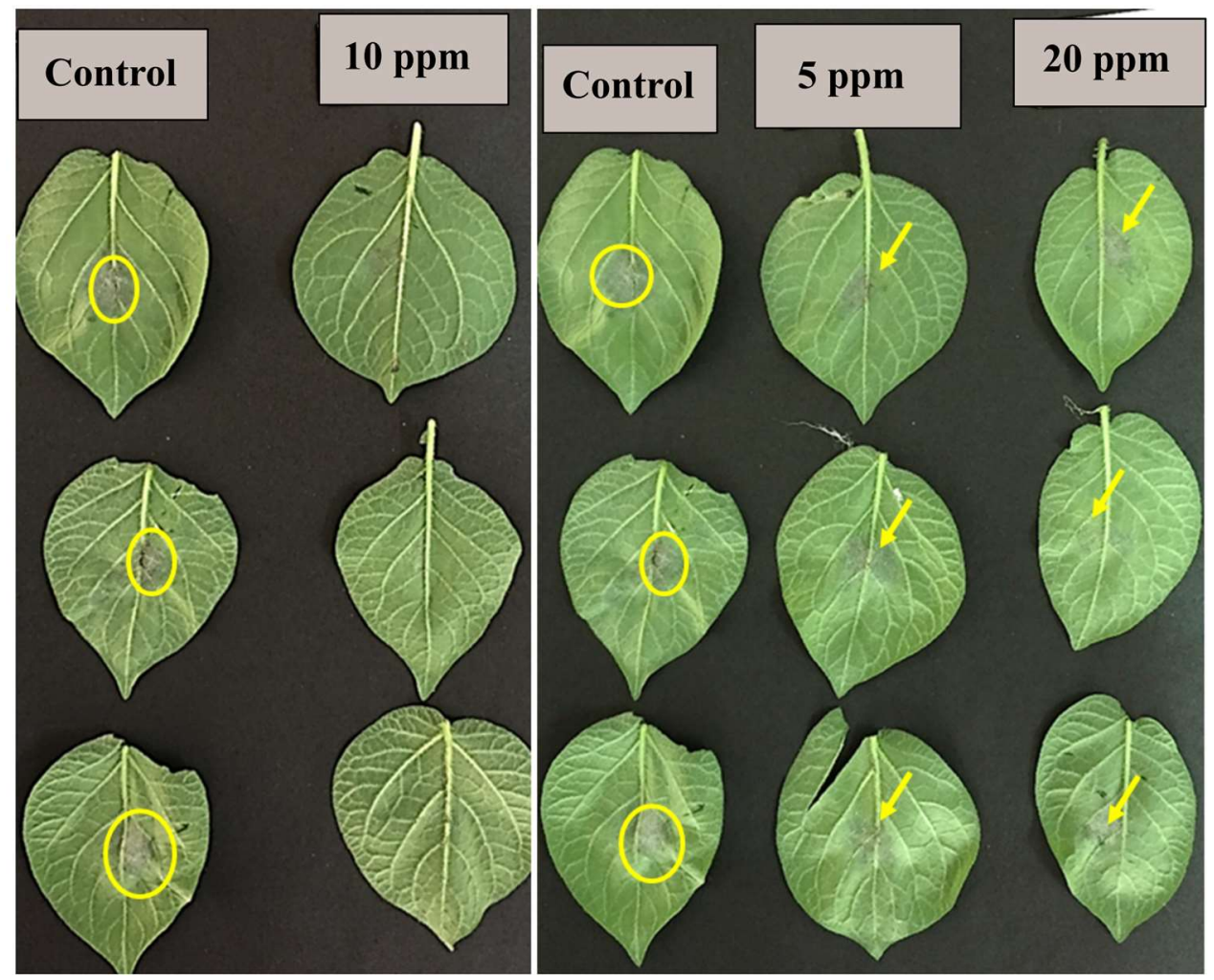

Figure 4. The effect of dsRNA with nano clay particle on late blight development. $200 \mathrm{ng} / \mathrm{ul}$ of GPI-HAM34 and PLD-3 with 5 ppm, 10 ppm and 20 ppm of nano clay.

\subsection{SIGS of P.infestans genes (single and multigene targeted dsR $\mathrm{NA}$ ) on disease development}

dsRNA expressed in IPTG (Isopropyl $\beta$-D-1-thiogalactopyranoside) induced T7 bacterial cells (see details in material and methods) was analysed using northern blot technique and showed the expression of dsRNA specific to EF-1 $\alpha$, SDH and Hsp90 encoding genes (Supplementary Figure 4). Pelleted T7 cells harbouring dsRNA molecules were mixed with the sterile RNase free water and tween 20. This dsRNA formulation mixture was sprayed on 30-day old potato plant (KB) in late blight screening chamber (detail material and methods). KB challenge inoculated by P.infestans sporangial zoospores were sprayed by dsRNA at $24 \mathrm{hr}$ intervals. Disease symptoms started appearing in control plants from the $3^{\text {rd }}$ day after disease inoculation. The control plants displayed $80 \%$ terminal disease severity at $5^{\text {th }}$ day after inoculation while the plants sprayed with dsRNA displayed $10 \%$ terminal disease severity after the same duration. The individual spray of dsRNA containing EF-1 $\alpha$, SDH and Hsp90 encoding genes showed a disease severity range of $20 \%$ to $24 \%$, a combination of three gene dsRNA solutions showed a disease severity of only $10 \%$ (Figure 5). Only the control plants showed profused sporulation while none of the dsRNA sprayed plants showed sporulation. The water sprayed and T7 cells sprayed control plants was not showed soignifincat difference in disease severity and sporulation of the pathogen. 

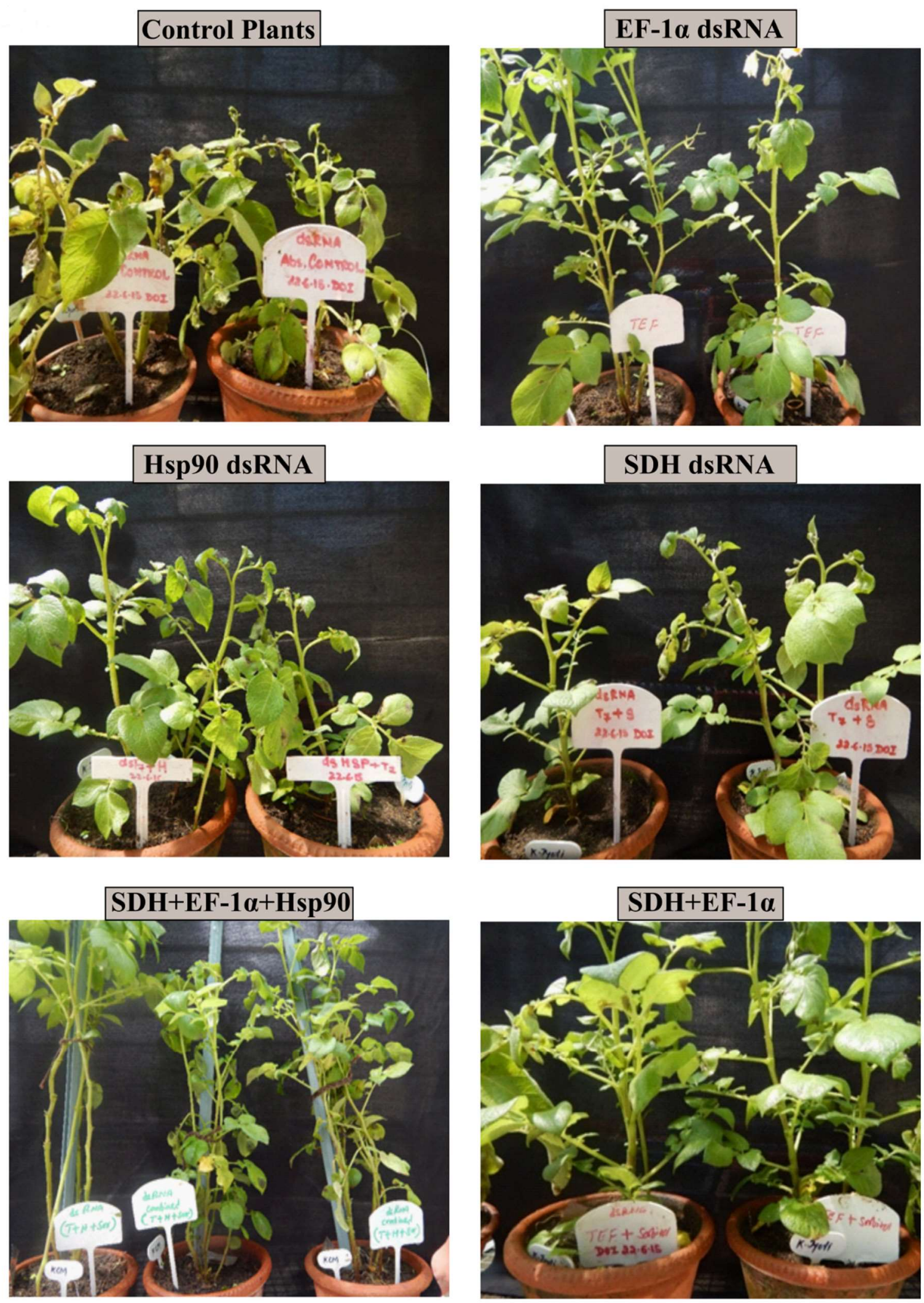

Figure 5. The effect of naked dsRNA spray (EF-1 $\alpha$, SDH, Hsp90 individually and in multiple combinations of $\mathrm{EF}-1 \alpha+\mathrm{SDH}+\mathrm{Hsp} 90$ ) against late blight of potato. 


\subsection{Efficacy of dsRNA-nano clay formulation (multi gene targeted dsRNA)}

A long dsRNA fragment (640 bp) targeting five P. infestans genes namely SDH, EF-1 $\alpha$, Hsp90, PLD-3 and GPI-HAM34 integrated into a single construct were subjected to dsRNA synthesis and their efficacy of reducing the symptom development was analysed using detached leaf assay. The results showed a significant reduction in symptoms with minimum lesion area and negligible spore formation. For topical application, multi gene targeted dsRNA carrying T7 express were mixed with $0.5 \%$ nano clay solution ( $5 \mathrm{gm}$ in $1 \mathrm{lt}$ ). Under open condition, we used higher concentration of dsRNA and nano clay to protect from RNAse and to enhance the effective delivery and RNAi efficicency. Late blight susceptible KB was sprayed with dsRNA-nano clay formulation using automizer and maintained under late blight screening chamber. A $24 \mathrm{hr}$ after dsRNA sprayed KB plants were challenge inoculated and maintained at $18^{\circ} \mathrm{C}$ temperature and $90 \%$ relative humidity. $5-10 \%$ symptoms started to appear in the control plants at $60 \mathrm{hpi}$ (hours post inoculation). At 120 hpi, control plants showed a maximum of $80 \%$ disease severity with huge sporulation $\left(5 \times 10^{3}\right)$. While the dsRNA nano clay sprayed KB plants showed 5\% disease severity with no sporulation (Figures 6 and 7). We observed this phenotypic differences up to 15 days, where the control plants were completely collapsed and wilted while dsRNA nano clay sprayed plants were erect and healthy. This indicates that dsRNA reduces the late blight disease progression by arresting the life cycle of the pathogen.
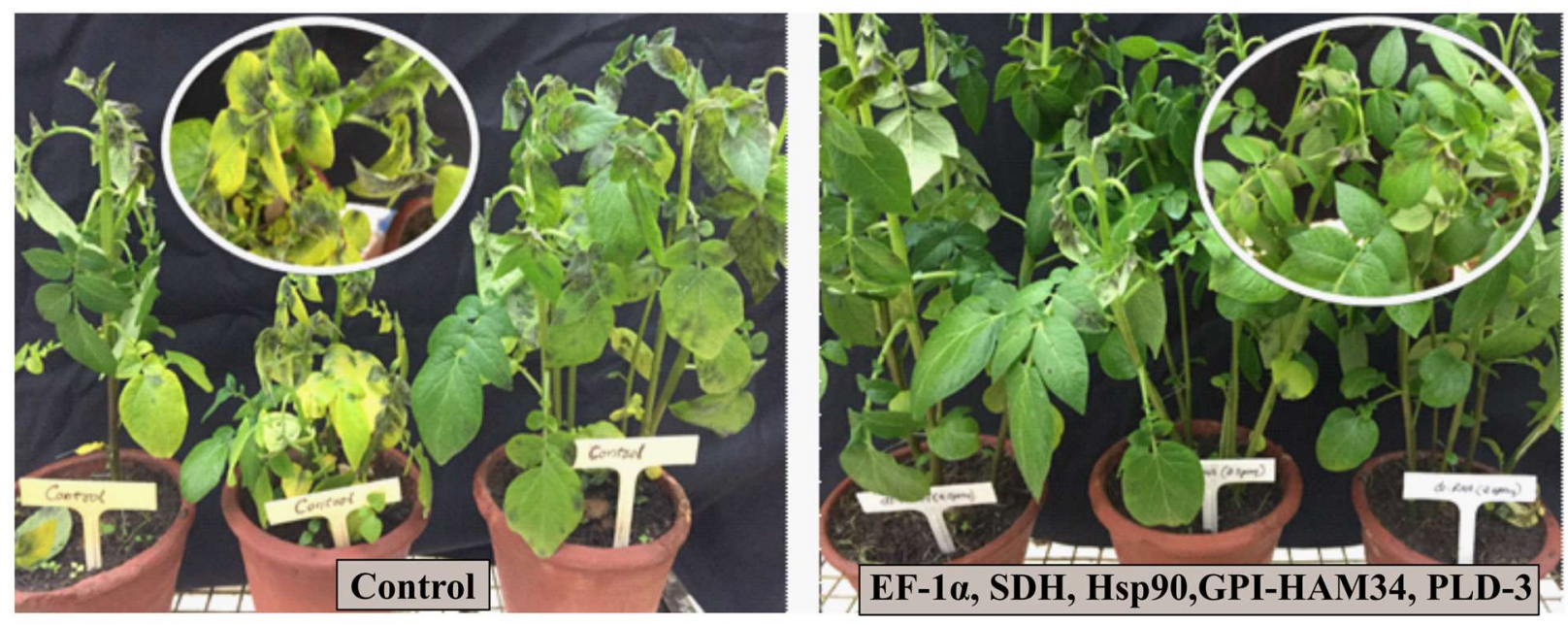

Figure 6. Efficacy of dsRNA -nano clay spray (EF-1 $\alpha$, SDH, Hsp90, GPI-HAM34 and PLD3) against late blight as topical spray method. 


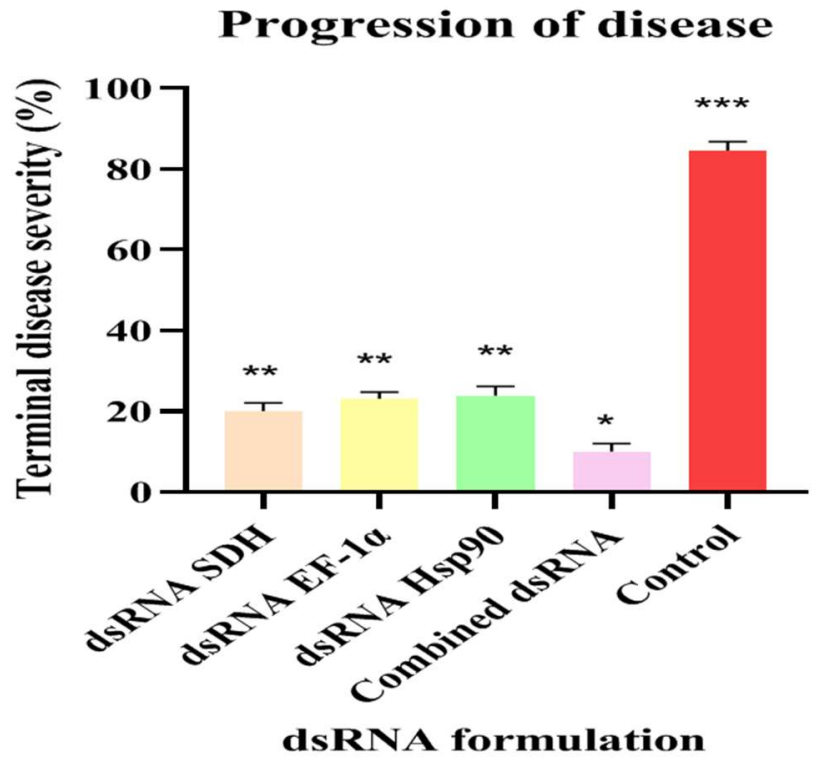

Figure 7. Late blight disease progression in relation to the percentage of infection. The graphs show the progression of disease at $120 \mathrm{hrs}$ in terms of disease severity. Disease severity was calculated according to Malcolmson (1976). The percentage of the lesion area was scored according to the severity of infection: $25-40 \%$ lesion area was categorized as moderate resistance, while an $80 \%$ lesion area was categorized as a susceptible reaction.

The statistical significance of differences between water sprayed control plants and dsRNA sprayed plants was analysed by unpaired student T-test using GraphPad PRISM 8 software with significantly different means $(\mathrm{p}<0.05)$. Experimental data are average of three biological replicates. Asterisks represent values significantly different from those of control $(* \mathrm{P}<0.05$, $\left.* * \mathrm{P}<0.01,{ }^{*} * * \mathrm{P}<0.001\right)$. Error bars represent mean \pm SEM.

\subsection{Uptake of dsRNA in potato leaf tissues}

Confocal imaging of cy3 labelled dsRNA sprayed potato plants confirms the absorption and uptake of dsRNA. A single panel imaging of dsRNA treated leaves showed positive fluorescence, suggesting the uptake of dsRNA by leaf cells, whereas the untreated dsRNA leaf showed minimal fluorescence in their trichomes (Figure 8). 
a

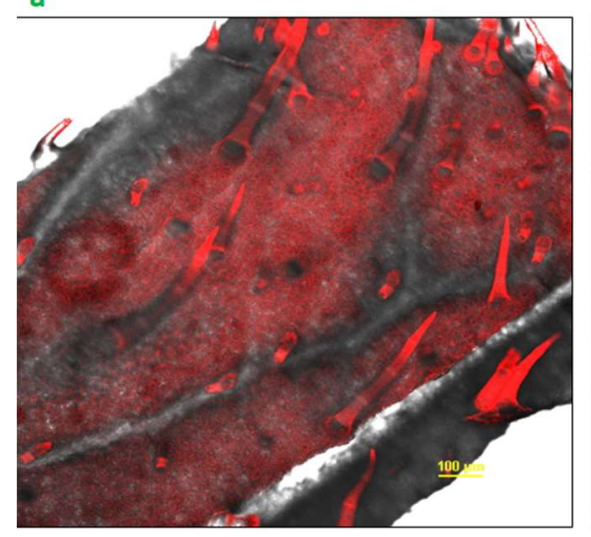

b

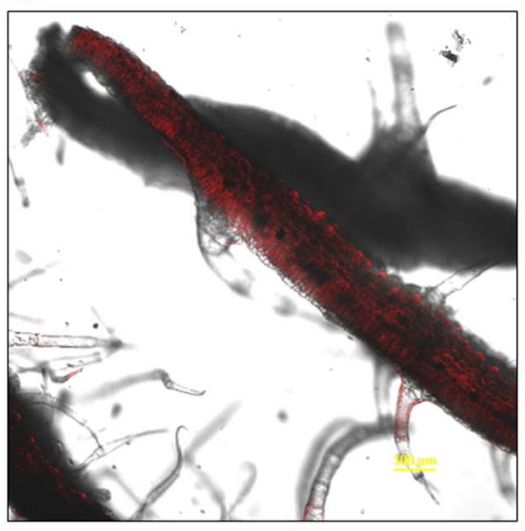

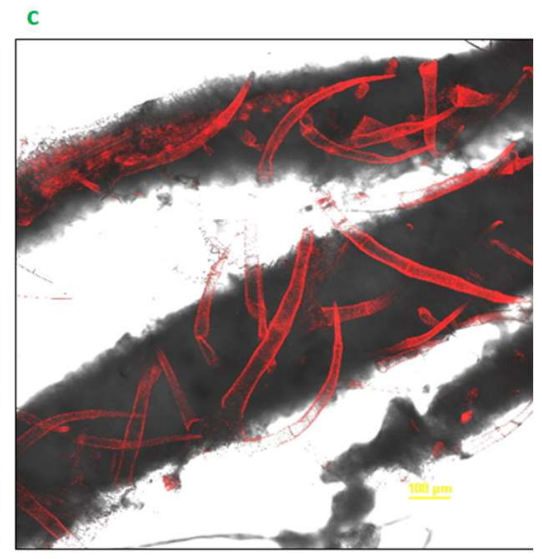

Figure 8. Confocal microscope images of potato leaf tissue after spraying of cy3 labelled dsRNA a). Leaf cross section showing uptake of dsRNA in the leaf tissue (Adaxial leaf surface) b). cross section of leaf tissue showing cy3 flourescence compare to c). control leaf sction showed minimal autoflourescce for only trichomes.

\subsection{Relative Quantification of relevant gene expression in dsRNA sprayed plants}

The effects of dsRNA molecules on target genes was examined in the dsRNA treated (resistant) and control (susceptible) plants by qRT-PCR (Quantitative Reverse Transcription Polymerase Chain Reaction) analysis. When sprayed individually there was a significant reduction of pathogen transcripts in the dsRNA treated leaves while the control plants had a higher number of transcripts with the highest RQ (relative quantification) value of 1 . Transcript levels of selected genes were significantly decreased with the range of 0.23 to 0.75 compared to an increased level of the transcripts ( $>10$ fold, according to ABI real time SD RQ manager normalise the control sample RQ value as 1) in control leaf samples (Figure 9a). Multi gene targeted dsRNA resulted in a significant reduction in transcripts, compared to individual spray and control plants. The individual transcripts showed 0.023 to 1.0 fold expression (Sorbitol: 0.02, TEF: 1 and HSP90: 0.96) compared to control plants which showed $>10$ fold expression of the pathogen transcript level (ABI SD_RQ manager normalise the transcript of pathogen endogenous gene with the target pathogen gene, resulted in normalised RQ value as 1) (Figure 9b). dsRNA presumably led to inhibition of pathogen gene expression during the pathogen interaction with the plant cells. The reduced expression also coincided with less disease progression in the plants, i.e., decreased terminal disease severity. 


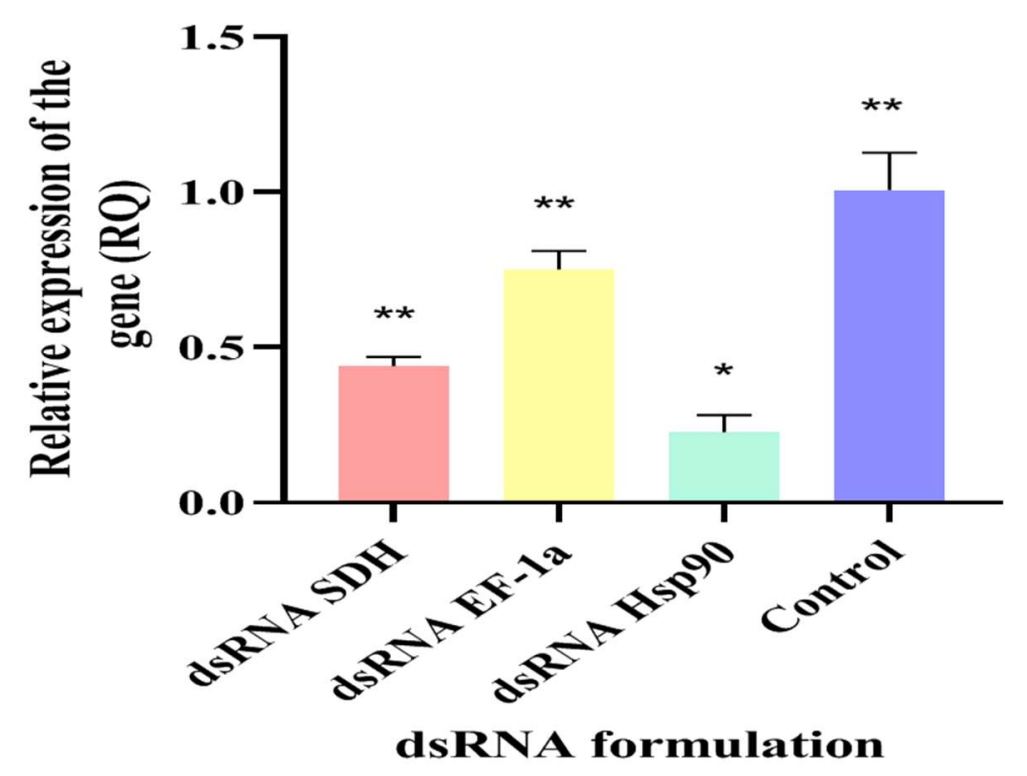

(a)

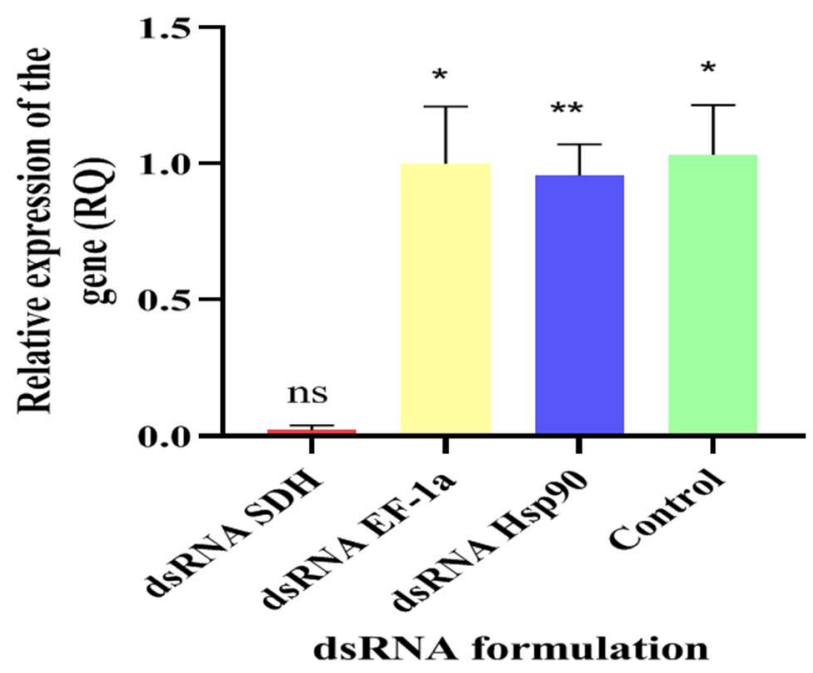

(b)

Figure 9. qRT-PCR analysis of dsRNA sprayed plants to validate the resistance nature of the plants. Quantitative expression of targeted genes in individual dsRNA (EF-1 $\alpha$, SDH and Hsp90 genes) sprayed plants in comparison to the water sprayed control plants. b)Quantitative expression of targeted genes in multi gene targeted dsRNA treated plants in comparison to the water sprayed control plants.Relative expression value of the sample was normalised with control sample value. Compared to dsRNA sprayed plants, there was a significant increase level of the transcript in control leaf samples ( $>10$ fold) according to ABI real-time SD RQ manager normalise the control sample RQ value as 1 . The statistical significance of differences between water sprayed control plants and dsRNA sprayed plants was analysed by unpaired student T-test using GraphPad PRISM 8 software with significantly different means $(p<0.05)$. Experimental data are average of three biological replicates. Asterisks represent values significantly different from those of control $(* \mathrm{P}<0.05, * * \mathrm{P}<0.01, * * * \mathrm{P}<0.001)$. Error bars represent mean \pm SEM. Transcript levels quantified by qRT-PCR analyses of EF-1 $\alpha$, SDH and 
Hsp90 encoding gene from the dsRNA sprayed plants as individual spray and multi dsRNA solution sprayed plants.

\section{Discussion}

Currently, the control of oomycetes destructive pathogen P.infestans is still a challenge due to its extraordinary adaptation to host and disease management strategies, especially fungicides and resistant varieties (5Fry, 2008). The asexual cycle of sporangial proliferation is completed within five days. Depending on environmental conditions, an unprotected potato field with a susceptible cultivar can be destroyed within ten days after this pathogen infection (5Fry, 2008). On infection, the haustorium produces effector proteins that can be recognized by the potato plant. When the host carries a corresponding $\mathrm{R}$ (Resistance) gene, it causes a hypersensitivity reaction (HR) in the host. $P$. infestans requires a diverse pool of effectors and the rapid evolution of these effectors to break the host resistance. The $\mathrm{R}$ genes of the host are also under strong selective pressure for the recognition of pathogen effectors for successful hypersensitive response and manage the pathogen infection (35Haverkort et al., 2009).

In the last few years, stable plant transformation based HIGS system has been proven to efficiently control pests, nematodes, oomycete, filamentous pathogens and parasites in various plant models and crop species by the direct spray of dsRNAs targeting a specific pathogen causing transient or stable pathogen gene expression [14-15, 36-47]. In HIGS, host (potato plant) produces siRNA having sequence homology to the specific fungal ( $P$. infestans) gene(s) sequences, which have been already proved in our earlier studies and it was conceptualised that a single effector is not sufficient to arrest the progression of the pathogen in potato [11]. HIGS has been proved as a promising alternative to fungicides for the management of a number of diseases [48]. These scientific evidence support our present study and demonstrate a novel way to investigate and establish the for controlling fungal diseases.

Here we establish the transfer of siRNA into $P$. infestans through an exogenous spray of target specific dsRNA. This interrupts the molecular interaction between the pathogen and the host by directly or indirectly silencing virulence along with inhibiting the synthesis of housekeeping proteins like (SDH) for sporulation, (EF-1 $\alpha$ ) for protein synthesis, (GPI-HAM34) for cell membrane biosynthesis, signalling and adhesion,(PLD-3) for encystment of zoospores and intracellular signal transduction and (Hsp90) for defence against stress using dsRNA technology to suppress the life cycle and disease (late blight) progression of $P$. infestans. Microarray data suggested that a number of genes unique to different stages in $P$. infestans life cycle were upregulated at a specific temperature, indicating that temperature plays an important role in regulating the genes in sporangium $\left(18^{\circ} \mathrm{C}\right)$ and zoospores $\left(4^{\circ} \mathrm{C}\right)$. Similar results were reported by $[49,50,51]$.

dsRNA was synthesized separately by using single gene targeted construct as well as long dsRNA fragment construct that carried five target genes (EF-1 $\alpha, S D H$, Hsp90, PLD-3 and GPIHAM34). This dsRNA was applied to the pathogen culture in combination as $S D H, H s p 90, E F$ 1a, GPI-HAM34, and PLD-3 genes. This resulted in the 70\% inhibition of mycelium growth in in vitro culture assay. For topical application, dsRNA fragment carrying five genes in one experimental set up and individual targeted gene in another experimental set up was sprayed as aerosol formulation, as naked dsRNA as well as with nano clay solution on the challenge inoculated KB.

Studies have demonstrated the role of the open air environmental spray of dsRNA in inducing the infection of Fusarium graminearum in the leaves of barley [22] and the infection of 
S. sclerotiorum in canola roots [52]. The present study demonstrates in similar way of open air environment spraying of dsRNA causes a reduction in the number of sporangial zoospores, lesion area and little to almost no symptom development in challenged KB plants. According to our investigation, the effect of several dsRNAs targeting multiple genes is required as dsRNA concentration determine the inhibitory effect on pathogen growth and disease progression. This was demonstrated by a significant difference in leaf lesion area $\left(0.8 \mathrm{~cm}^{2}\right.$ to $2.5 \mathrm{~cm}^{2}$ without nano clay-dsRNA formulation and 0.2 to $1.2 \mathrm{~cm}^{2}$ with nano clay-dsRNA formulation, compared to 7.8 in control), sporulation ( $0 \times 10^{3}$ to $3 \times 10^{3}$ without nano clay-dsRNA formulation and $0 \times 10^{3}$ to $1 \times 10^{3}$ with nano clay-dsRNA formulation, compared to control $8.5 \times 10^{3}$ ) and reduced terminal disease severity from $23 \%$ to $4 \%$ ( $23 \%$ in naked dsRNA treatment assay and $4 \%$ in nano clay-dsRNA treatment assay, compared to $73 \%$ in control, water sprayed). This is strongly supported by our earlier studies which stated that single effector is not sufficient to impart complete resistance against the pathogen [11]. This is the first report on the external application of dsRNA on potato to reduce infection and symptom development.

Detached leaf assay, topical application of single gene targeted and multi gene targted naked dsRNA and dsRNA with nano clay formulation showed a varied response to pathogen development with varied dsRNA concentration. In detached leaf assay and culture bioassay, minimal dsRNA concentration showed promising results, where as in topical application, higher concentration of dsRNA act RNAi effect in inhibition of sporulation and symptom progression with nano clay as a carrier, this may clearly indicated that, effect of RNAse activity under in vitro (culture bioassay) and in vivo assay (topical application). This is in supporting with the earlier research groups, demonstrated that that RNA molecule with nano clay carrier showed a more aggressive response to resistance against plant viruses and fungal pathogens [22,23a,53]. Highpressure spray of dsRNA-nano clay formulation facilitates symplastic movement and effective delivery of the RNA molecules. These findings are supported by the studies that showed that apoplastic movement of small RNA through petiole absorption and a high-pressure spray of small RNAs have shown to be effective RNAi strategies against fungi and aphid insects due to symplastic movement of sprayed RNA molecules [54,55]. Cy3 labelled dsRNA in potato sprayed plants using confocal imaging system is depicted in (Figure 8) and has been scientifically proven in various plant-insect interaction studies [56]. This may efficiently initiate the RNAi effect on target genes and inhibited the expression of mRNA.The probable cross kingdom mechanism of movement of siRNA and dsRNA carrying the target genes is processed in a sequential and stepwise RNAi process for SIGS mechanisms.

\subsection{Effect of dsRNA on gene suppression}

Ds RNA encoding the SDH inhibited the sporulation in detached leaf assay and in whole plant bioassay. Negligible sporulation count and minimum expression of symptoms (Figures 2 and 5 and Table S2 and S3) strongly correlate with scientific evidence that showed that sorbitol is involved in the cellular process of sporangia and identified the potential targets for plant protection strategies [57]. Thus a probable reason for the reduction in disease development in the plants sprayed with ds RNA of SDH encoding genes could be a seizure in various vital metabolic pathways of due to the silencing of SDH encoding gene.

Reduction in disease development in the plants sprayed with ds RNA of PLD-3 encoding genes (Table S2) might be the inhibition of its primary signalling pathways and impediment of sporulation and encystment of $P$. infestans. 
The GPI transmembrane anchors in the cell wall remodelling enzymes could probably be used during hyphal extension by the pathogenic fungi and disease progression $[58,25,59,60]$. This could possibly explain the inhibition of disease progression and symptom development in dsRNA sprayed plants with GPI-HAM34 encoding gene sequence. These findings have been strongly supported the present study, which revealed that least disease severity and sporulation in the dsRNA combination of GPI-HAM34 and PLD-3. This is due to the broad molecular function of these genes in pathogen physiology and morphogenesis.

$E F-1 \alpha$ gene is universally reported as translation factor in protein synthetic machinery and which governs actin cytoskeleton of the fungal cells by mediating the hydrolysis of GTP and formation of the peptide bond $[61,26]$. Inhibition of EF-1 $\alpha$ encoding gene caused a reduction in disease and symptom development in dsRNA sprayed plants (Figs 2-5 and Table S1). This could be due to the arrest of protein synthesis machinery, which could possibly lead to the inhibition of the developmental cycle and vital enzyme based cellular processes of $P$. infestans. Besides, reduced expression of all the above dsRNA targeted genes quantified the dsRNA assay efficiently (Figs. 9a, 9b), though small RNA expression data were not clearly showed the significant results, between control and dsRNA sprayed plants, probably due to copy number of the genes (unpublished data). Overall the study conceptualised the application of dsRNA with nano clay and it would be the best option to deliver dsRNA and efficient action of RNAi to inhibit the growth and disease progressions. We have summarised the overall results of this study in Figure 10, which illustrates a probable model for dsRNA transport and P.infestans gene silencing. 


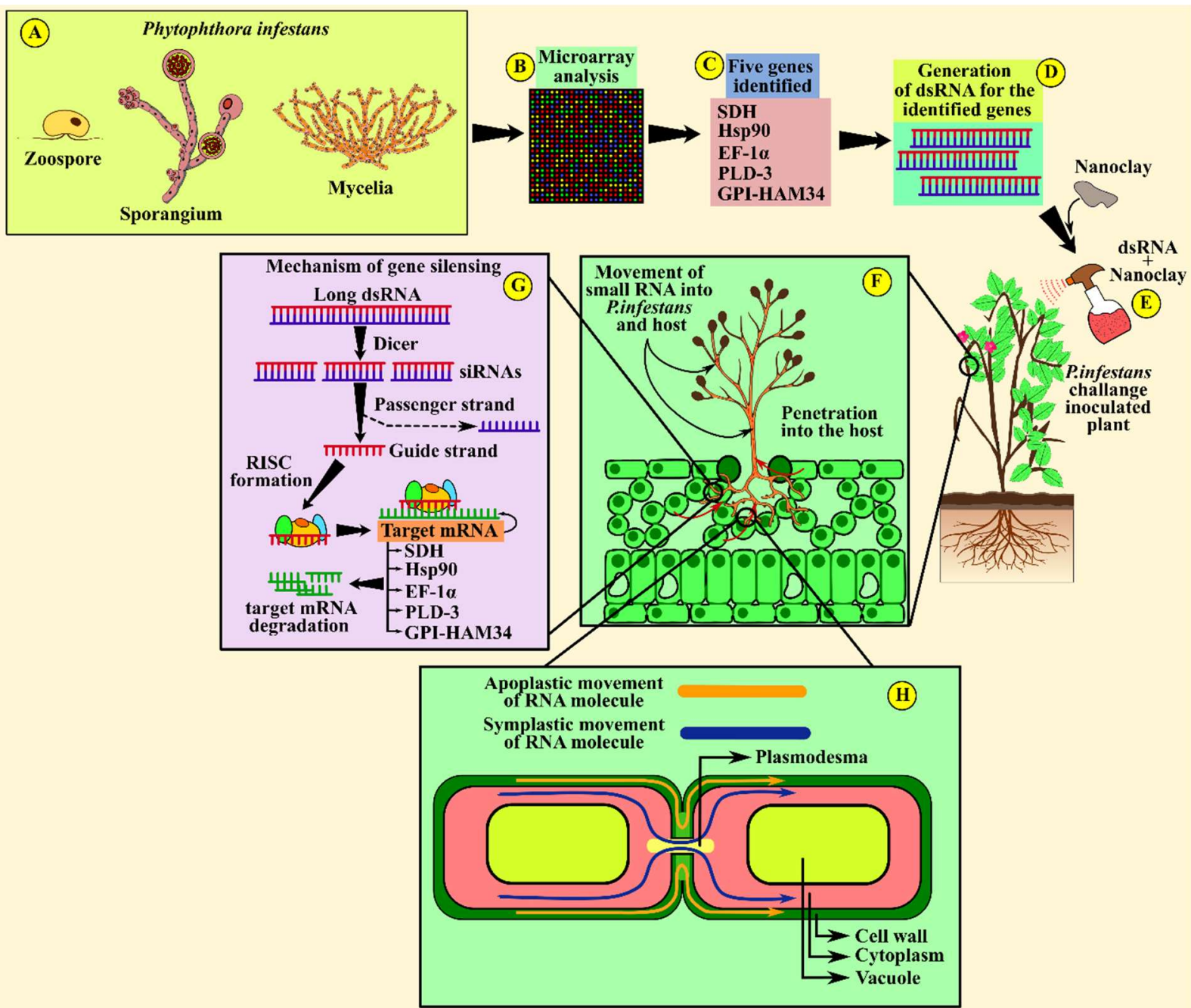

Figure 10. Illustration of experimental procedure and mechanism of $P$.infestans gene silencing by spray induced gene silencing. A) Mycelia, sporangia and zoospores of P.infestans. B) Microarray analysis using cDNA of mycelia, sporangia and zoospores was performed to decipher these stages at a transcriptome level. C) Identification of highly upregulated five genes, soribitol dehydrogenase (SDH), heat shock protein 90 (Hsp90), translation elongation factor 1- $\alpha$ (EF-1 $\alpha)$, phospholipase-D like 3 (PLD-3) and glycosylphosphatidylinositolanchored acidic serine-threonine rich HAM34-like protein (GPI-HAM34). D) Generation of dsRNA for these five genes. E) Spraying of dsRNA-nano clay formulation on P.infestans challenge inoculated plants. F) Penetration of P.infestans into the host plant. G) Mechanism of genes silencing by RNAi. dsRNA is acted upon by RNase-III-type endonucleases called Dicer specific to dsRNA and cleaves it into smaller 21-23 nucleotide long dsRNA intermediates. These dsRNA intermediates are then acted upon by RNA helicase and other accessory proteins to form a single-stranded siRNA-containing RNA-induced silencing complex (RISC). siRNA having sequence complementarity to the target RNA serves as guide RNA while the other strand called passenger RNA is degraded. RISC then guides the sequence-specific degradation of near-complementary or complementary target mRNAs of the target genes whose information was present in the dsRNA. H) Movement of small RNA into the host via apoplastic and symplastic movement. 


\subsection{Hypothesis of Movement of dsRNA and summary of SIGS gainst P.infestans}

However, dsRNA induced downregulation of gene expression in P.infestans revealed by qRTPCR and decrease in symptom development revealed by detached leaf assay (apoplastic movement of dsRNA), sporangial zoospores number, lesion area clearly indicate the uptake of topically applied dsRNA and its systemic movement (symplastic movement in topical application) in the host cell and its integration into P.infestans, subsequently initiating RNAi-mediated target gene silencing. Similar results were obtained when Small RNAs which target DCL2 and DCL1 genes of $B$. cinerea, causing grey mould, were sprayed on tomato and Arabidopsis, these plants acquired resistance against grey mould, proving that exogenously applied small RNAs enter the pathogen and interfere with its growth and progression [62]. The foliar application of in vitro transcribed dsRNA targeting Sclerotinia sclerotium and Botrytis cinerea conferred resistance in Brassica napus [63]. More recently, spraying of in vitro transcribed dsRNA targeting the myosine 5 of Fusarium asiaticum in wounded wheat (Triticum aestivum) coleoptiles resulted in reduced fungal virulence [64]. Recent studies from the Hailing Jin laboratory [65,66] have clearly established the concept of bi-directional trans kingdom transport of siRNAs and mechanistic details of RNA transport between plants and fungi. $B$. cinerea was able not only to deliver siRNAs into host plant cells to suppress host immunity genes but also uptake exogenously applied dsRNAs and siRNAs that inhibit its growth [67,62]. Although it is still not clearly defined how the invitro applied dsRNA travels into the pathogen cells to downregulate the expression of the target genes. Studies indicate that the small RNAs can be transferred between tissues and cells, inside an organism by either symplast (direct internal connection) or apoplast (externally).

Use of transient gene silencing was first reports in $P$. infestans by direct in vitro delivering of synthesized dsRNA in its protoplast [68]. A study proves the secretion of extracellular membrane vesicles called exosomes assist the delivery and transport of small RNAs between Arabidopsis and pathogenic fungi Botrytis cinerea. These exosomes deliver the host small RNAs to the fungi and silence their infection and virulence genes [69]. P. infestans produces haustorium, which penetrates the host cells serving as a portal for the secretion of proteins, signal molecules, virulence effectors and nutrient uptake [70]. Haustoria consist of extrahaustorial matrix and extrahaustorial membrane, the major sites for cellular exchange and transport between the host and the pathogen. A similar phenomenon was also reported in P.infestans where haustoria was established as the primary point of connection and transport of effector and signalling proteins [65]. Though we did not attempt to show microscopically, studies claim that these sites can serve as major points of small RNA transport to the fungal cells [71]. Moreover, the endogenous transport of RNAs from the host to the fungal pathogen might not be just a concentrationdependent diffusion but is a selective and complex mechanism [72].

Numerous studies have aimed to reveal that the gene silencing of the pathogen (fungi) cannot be monitored until the formation of haustoria. Effective silencing was observed after the haustorial structure formation and silencing was more efficient against the genes that were greatly expressed in the haustoria then that expressed in other parts of the plants $[73,74]$. These findings clearly indicate that the siRNA moves into the pathogen from the host through haustoria or similar structures and also that membrane-bound extracellular vesicles of plants are most probable determinants for RNA delivery into the pathogen [71-74]. In the pathosystem of P.infestans the HIGS signals (RNAs) could have possibly travelled from host to the parasite (P.infestans) by using the haustorial interphase and using vesicle-mediated transport using exosomes. Though experimental evidence is required to support and validate this hypothesis. 
Spraying of dsRNA molecule (SIGS) provides an easy and environmentally friendly approach, as it does not leave any toxic residues in soil and there are fewer chances of resistance development compared to chemical fungicides. In future, the utility and versatile action of dsRNA molecule will become a new plant protection strategy and as a viable next-generation fungicide/biomolecule for food safety and agricultural production in an eco-friendly and sustainable manner. We are hopeful that this technology would result in the development of ecofriendly potential biomolecule in the field of agriculture as a new plant protection strategy. Further, our strategy relies on the use of 'RNAi-based crop protection' as an exciting and promising option due to greater and diverse utility of dsRNA.

Author contribution: SS, SSh Planned and developed the project, SS, NS, KT raised the plant material. SS, MT, NS, KT, contributed to physiological studies and molecular characterisation and carried out all the wet lab experiments. SS, JA, RB, RK contributed the microarray and data analysis. SS, VB, Sh, BS, SKC corrected manuscript and mentored the whole study. SS, MT, wrote the MS. All authors have read and approved the MS.

Funding: We are thankful to the Phytophthora, Fusarium, and Ralstonia Disease of Horticultural Crops Project (PhytoFuRa), Indian Council of Agricultural Research, New Delhi, and ICARCentral Potato Research Institute (CPRI), Shimla, Himachal Pradesh for their financial support.

Conflict of interest: The authors declare that they have no known competing interest in authorship and to influence the work reported in this paper

\section{Supplementary Data:}

Figure S1. Cluster gram shows the different classes of gene expression profiles. A total of 18,078 Phytophthora infestans genes 116 genes were classified as unique genes and belongs to mycelium, sporangium, zoospores and Kufri Bahar infected samples (sample was withdrawn at $24 \mathrm{hr}$ after challenge inoculation). Each column represents the different stages of the Phytophthora infestans, whereas each row represents the expression profile of each gene over the different stages of Phytophthora. For each gene, the ratio of mRNA level in Mycelium, sporangium, zoospores and Kufri Bahar infected samples is represented by colour, according to colour scale at the bottom. Red, blue, yellow and grey colour represents the transcriptional activation, transcriptional repression, no difference and non-expression or weak signal respectively.

Fig. S2. Venn Diagram shows the expression of unique genes in (a) sporangium, (b) zoospores and (c) Kufri Bahar 24hrs infected samples.

Fig. S3. Confirmation of positive clones of P.infestans genes and dsRNA synthesis.

3a. EF-1 $\alpha$, Hsp90, SDH, GPI-HAM34 and PLD-3 dsRNA gel electrophoresis, depicts fragment size with smear background compared to pure PCR product. 3bRestriction analysis of positive clones of the L4404_GPI-HAM34, L4404_PLD-3, EF-1 $\alpha$, Hsp90, SDH encoding genes

Figure S4. Northern blot analysis of EF-1 $\alpha$, Hsp90 and SDH derived small RNA.

Figure S5. The Vector map of L4404

Table S1: Efficacy of dsRNA against P.infestans using detached leaf assay 
Table S2: Efficacy of dsRNA (GPI-HAM34 and PLD-3 gene) against P.infestans with and without nano clay particle using detached leaf assay

Table S3. Whole plant assay: dsRNA Nano clay spray against P.infestans sporulation

Table S4: Whole plant assay: dsRNA Nano clay formulation against late blight disease severity $(\%)$

\section{Microarray Data files}

S1: KJRB lines_0hr differentially expressed gene profile S1 Supplementary file 1

S2: KJRB_24hr differentially expressed gene profile S2 Supplementary file 2

S3: KJRB_72hr differentially expressed gene profile S3 Supplementary file 3

S4: KJRB_120hr differentially expressed gene profile S4 Supplementary file 4

S5: Cluster_Venn_24_72_Hrs S5 Supplementary file 5

S6: Gene list for gene ontology S6 Supplementary file 6

\section{References}

[1] J. Song, M. Bradeen, S.K. Naess, et al. Gene RB cloned from Solanum bulbocastanum confers broad spectrum resistance to potato late blight, Proc. Natl .Acade. Sci. U.S.A. 100 (2003) 91289133.

[2] A. Bourke, Potato blight in Europe in 1845: the scientific controversy. In: Lucas, J. A., Shattock, R.C., Shaw, D.S., Cooke, L.R. (Eds.), Phytophthora. Cambridge University Press, Cambridge (1991)12-24.

[3] A.J. Haverkort, P.M. Boonekamp, R. Hutten, E. Jacobsen, L.A.P. Lotz, G.J.T. Kessel, R.G.F. Visser, E.A.G. Van Der Vossen, Societal costs of late blight in potato and prospects of durable resistance through cisgenic modification, Potato Res. 51 (2008) 47-57.

[4] B. Kumbar, R. Mahmood, S.N. Nagesha, M.S. Nagaraja, D.G. Prashant, O.Z. Kerima, A. Karosiya, M. Chavan, Field application of Bacillus subtilis isolates for controlling late blight disease of potato caused by Phytophthora infestans. Biocatalysis and Agril. Biotechnol. 22 (2019) 101366. 10.1016/j.bcab.2019.101366

[5] W. Fry, 2008. Phytophthora infestans: The plant (and R gene) destroyer. Mol. Plant Pathol 9 (2008) 385-402.

[6] B.J. Haas, S. Kamoun, M.C. Zody, et al. 2009. Genome sequence and analysis of the Irish potato famine pathogen Phytophthora infestans. Nature 461 (2009) 393-398.

[7] G.J. Kettles, B.J. Hofinger, P. Hu, C. Bayon, J.J. Rudd, Dirk Balmer, Mikael Courbot, K.E. Hammond-Kosack, Gabriel Scalliet, Kostya Kanyuka, sRNA Profiling Combined With Gene Function Analysis Reveals a Lack of Evidence for Cross-Kingdom RNAi in the Wheat Zymoseptoria tritici Pathosystem. Frontiers in Plant Sci. 10 (2019) 892.

[8] A.M.V. Ah Fong, C.A. Bormann-Chung, H.S. Judelson, Optimization of transgene-mediated silencing in Phytophthora infestans and its association with small interfering RNAs. Fungal Genet. Biol. 45 (2008) 1197-1205. 
[9] J.I. Bos, M.R. Armstrong, E.M. Gilroy, P.C. Boevink, I. Hein, R.M. Taylor, T. Zhendong, S. Engelhardt, R.R.Vetukuri, B. Harrower, C. Dixelius, G. Bryan, A. Sadanandom A, Whisson SC, Kamoun S, P.R. Birch, Phytophthora infestans effector Avr3a is essential for virulence and manipulates plant immunity by stabilizing host E3 ligase CMPG1. Proc. Natl. Acad. Sci. U.S.A. 107 (2010) 9909-9914.

[10] S. Jahan, A.K.M. Asman, P. Corcoran, J. Fogelqvist, R. Vetukuri, C. Dixelius, Plant-mediated gene silencing restricts growth of the potato late blight pathogen Phytophthora infestans. J. Experimental Botany, 66 (2015) 2785-2794.

[11] S. Sanju, S. Siddappa, A. Thakur, P.K. Shukla, N. Srivastava, D. Pattanayak, S. Sharma, B.P.Singh, Host-mediated gene silencing of a single effector gene from the potato pathogen Phytophthora infestans imparts partial resistance to late blight disease. Functional and Integrative Genomics 15 (2015) 697-706.

[12] O. Bilir, O. Telli, C. Norman, H. Budak, Y. Hong, M. Tor, Small RNA inhibits infection by downy mildew pathogen Hyaloperonospora arabidopsidis, Mol. Plant Pathol. 20 (2019) 15231534.

[13] F. Dunker, A. Trutzenberg, J.A. Rothenpieler, S. Kuhn, Reinhard Pro, T. Schreiber, A. Tissier , A. Kemen, E. Kemen, Ralph Hu ckelhoven, A. Weiberg, Oomycete small RNAs bind to the plant RNA-induced silencing complex forVirulence. eLife 9 (2020) doi.org/10.7554/eLife.56096.

[14] D. Nowara, P. Schweizer, A. Gay, C. Lacomme, J. Shaw, C. Ridout, D. Douchkov, G. Hensel, J. Kumlehn, HIGS: Host-induced gene silencing in the obligate biotrophic fungal pathogen Blumeria graminis. Plant Cell 22 (2010) 3130-3141.

[15] C. Yin, J.E. Jurgenson, S.H. Hulbert, Development of a host-induced RNAi system in the wheat stripe rust fungus Puccinia striiformis $f$. $s p$. tritici. Mol. Plant-Microbe Interactions 24 (2011) 554-561.

[16] A. Koch, N. Kumar, L. Weber, H. Keller, J. Imani, K.H. Kogel, Host-induced gene silencing of cytochrome P450 lanosterol C14 $\alpha$-demethylase-encoding genes confers strong resistance to Fusarium species. Proc.Natl. Acad. Sci. U.S.A 110 (2013) 19324-19329.

[17] W. Cheng, X. Song, H. Li, L. Cao, K. Sun, X. Qiu, Y. Xu, P. Yang, Huang T, Zhang J, Qu B, Liao YC. 2015. Host-induced gene silencing of an essential chitin synthase gene confers durable resistance to Fusarium head blight and seedling blight in wheat. Plant Biotechnol J. 13 (2015)1335-1345.

[18] Y. Song, B.P.H.J. Thomma, Host-induced gene silencing compromises Verticillium wilt in tomato and Arabidopsis. Mol. Plant Pathol. 19 (2018) 77-89.

[19] X.Y. Guo, Y. Li, J. Fan, H. Xiong, F.X. Xu, J. Shi, Y. Shi, J.Q. Zhao, Y.F. Wang, X.L. Cao, W.M.Wang, Host-induced gene silencing of MoAPl confers broad-spectrum resistance to Magnaporthe oryzae. Frontiers in Plant Sci, 10 (2019) 433. 
[20] Y. Raruang, O. Olanike, D. Hu, Q. Wei Q, Zhu-Qiang Han, Kanniah Rajasekaran, W.C. Jeffrey W. C, Kan W, Zhi-Yuan, Z.Y. Chen, Host Induced Gene Silencing Targeting Aspergillus flavus aflM Reduced Aflatoxin Contamination in Transgenic Maize Under Field Conditions. Frontiers in Microbio. (2020) 754.

[21] P.C. Boevink, X. Wang, H. McLellan, et al. A Phytophthora infestans RXLR effector targets plant PP1c isoforms that promote late blight disease, Nature Commun. 7 (2016) 10311.

[22] A. Koch, D. Biedenkopf, A. Furch, et al., An RNAi-Based Control of Fusarium graminearum Infections through Spraying of Long dsRNAs involves a Plant Passage and is controlled by the Fungal Silencing Machinery, PLoS Pathogens, 12 (2016) e1005901.

[23a] N. Mitter, E.A. Worrall, K.A. Robinson, P. Li, R.G. Jain, C. Taochy, S.J. Fletcher, B.J. B.J.Carroll, J.Q. Lu, Z.P. Ping Xu, Clay nanosheets for topical delivery of RNAi for sustained protection against plant viruses, Nature Plants, 3 (2017) 1-10.

[23b] N. Mitter, E.A.Worrall, K.E. Robinson, Z.P. Xu, B.J. Carroll, Induction of virus resistance by exogenous application of double-stranded RNA, 26 (2017) 49-55.

[24] M. Wang, R.A. Dean, Movement of small RNAs in and between plants and fungi, Mol. Plant Pathol. 21 (2020) 589-601.

[25] A.M.V. Ah-Fong, J. Shrivastava, H.S. Judelson, Lifestyle, gene gain and loss, and transcriptional remodeling cause divergence in the transcriptomes of Phytophthora infestans and Pythium ultimum during potato tuber colonization, BMC Genomics 18 (2017) 764.

[26] M.K. Mateyak, J.K. Pupek, A.E. Garino, M.C. Knapp, S.F. Colmer, T.G. Kinzy, S. Dunaway, Demonstration of translation elongation factor 3 activity from a non-fungal species, Phytophthora infestans, PLoS ONE, 13 (2018) e0190524-1.

[27] M. Latijnhouwers, T. Munnik, F. Govers, Phospholipase D in Phytophthora infestans and its role in zoospore encystment, Mol. Plant-Microbe Interact. 15 (2002) 939-946.

[28] C. Caten, E.J.L. Jinks, Spontaneous variability of single isolates of Phytophthora infestans. I. Cultural variation, Canadian Journal of Botany 46 (1968) 329-347.

[29a] R.A. Irizarry, B.M. Bolstad, F. Collin, L.M. Cope, B. Hobbs, T.P. Speed, Summaries of Affymetrix GeneChip probe level data, Nucleic Acids Res. 31 (2003a): 1-8.

[29b] R.A. Irizarry, B. Hobbs, F. Collin, Y.D. Beazer-Barclay, K.J. Antonellis, U. Scherf, T.P. Speed, Exploration, normalization, and summaries of high density oligonucleotide array probe level data. Biostatistics (Oxford, England) 4 (2003b): 249-64.

[30] J.F. Malcolmson, Assessment of field resistance to blight (Phytophthora infestans) in potatoes, Trans British Mycological Society 67 (1976) 321-325.

[31] R.K. Birhman, B.P. Singh, Path-coefficient analyses and genetic parameters of the components of field resistance of potatoes to late blight, Ann. Appl. Biol. 127 (1995) 353-362.

[32] K.J. Livak, T.D. Schmittgen, Analysis of relative gene expression data using real-time quantitative PCR and the $2-\Delta \Delta C$ t method, Methods 25 (2001) $402-408$ 
[33] J. Sambrook, E.F. Fritsch, T. Maniatis, Molecular cloning: laboratory manual. $2^{\text {nd }}$ ed., Coldspring Harbor press (1989) New york.

[34] R. Sharma, V. Bhardwaj, Dalamu, S.K. Kaushik, B.P. Singh, S. Sharma, R. Umamaheshwari, B. Raigond, Kumar Vand, C. Gebhardt, Identification of elite potato genotypes possessing multiple disease resistance genes through molecular approaches, Scientia Horticulturae 179 (2014) 204211.

[35] A.J. Haverkort, P.C. Struik, R.G.F. Visser, E. Jacobsen, Applied biotechnology to combat late blight in potato caused by Phytophthora infestans, Potato Research 52 (2009) 249-264.

[36] J.A. Baum, T. Bogaert, W. Clinton, et al. Control of coleopteran insect pests through RNA interference, Nature Biotechnol. 25(2007) 1322-1326.

[37] Y.B. Mao, W.J. Cai, J.W. J.W. Wang, G.J. Hong, X.Y. Tao, L.J. Wang, Y.P. Huang, X.Y. Chen, Silencing a cotton bollworm P450 monooxygenase gene by plant-mediated RNAi impairs larval tolerance of gossypol, Nature Biotechnol. 25 (2007) 1307-1313.

[38] G. Huang, R. Allen, E.L. Davis, T.J. Baum, R.S. Hussey, Engineering broad root-knot resistance in transgenic plants by RNAi silencing of a conserved and essential root-knot nematode parasitism gene, Proc. Natl. Acad. Sci. U.S.A. 103 (2006) 14302-14306.

[39] D. Nowara, P. Schweizer, A. Gay, C. Lacomme, J. Shaw, C. Ridout, D. Douchkov, G. Hensel, J. Kumlehn, HIGS: Host-induced gene silencing in the obligate biotrophic fungal pathogen Blumeria graminis. Plant Cell 22 (2010) 3130-3141.

[40] A. Koch, N. Kumar, L. Weber, H. Keller, J. Imani, K.H. Kogel, Host-induced gene silencing of cytochrome P450 lanosterol C14 $\alpha$-demethylase-encoding genes confers strong resistance to Fusarium species, Proc. Natil. Acad. Sci. U.S.A., 110 (2013) 19324-19329.

[41] C.C. Nunes, R.A. Dean, Host-induced gene silencing: A tool for understanding fungal host interaction and for developing novel disease control strategies, Mol. Plant Pathol. 13 (2012) 519529.

[42] W. Chen, C. Kastner, D. Nowara, E. Oliveira-Garcia, T. Rutten, Y. Zhao, H.B. Deising, J. Kumlehn, P. Schweizer, Host-induced silencing of Fusarium culmorum genes protects wheat from infection, J.Expt. Botany, 67 (2016) 4979-4991.

[43] F. Tenllado, B. Martínez-García, M. Vargas, J.R. Díaz-Ruíz, Crude extracts of bacterially expressed dsRNA can be used to protect plants against virus infections, BMC Biotechnol, 3 (2003) 3.

[44] F. Tenllado, C. Llave, J.R. Díaz-Ruíz, RNA interference as a new biotechnological tool for the control of virus diseases in plants, Virus Res, 102 (2004) 85-96.

[45] M.Wang, H. Jin, Spray-Induced Gene Silencing: a Powerful Innovative Strategy for Crop Protection, Trends in Microbiol., 25 (2017) 4-6. 
[46] G. Yin, Z. Sun, N. Liu, L. Zhang, Y. Song, C. Zhu, F. Wen, Production of double-stranded RNA for interference with TMV infection utilizing a bacterial prokaryotic expression system, App. Microbiol. Biotechnol. 84 (2009) 323-333.

[47] G.H.Yin, Z.N. Sun, Y.Z. Song, H.L. An, C.X. Zhu, F.J. Wen, Bacterially expressed doublestranded RNAs against hot-spot sequences of tobacco mosaic virus or potato virus y genome have different ability to protect tobacco from viral infection, App. Biochem.Biotechnol. 162 (2010) 1901-1914.

[48] D. Hu, Z.Y. Chen, C. Zhang, M. Ganiger, Reduction of Phakopsora pachyrhizi infection on soybean through host- and spray-induced gene silencing, Mol. Plant Pathol. 21 (2020)794-807.

[49] L. Englander, M. Browning, P.W. Tooley, Growth and sporulation of Phytophthora ramorum in vitro in response to temperature and light, Mycologia 98 (2006) 365-373.

[50] J.M.N. Maziero, L.A. Maffia, E.S.G. Mizubuti, Effects of temperature on events in the infection cycle of two clonal lineages of Phytophthora infestans causing late blight on tomato and potato in Brazil, Plant Disease 93 (2009) 459-466.

[51] S. Tani, E.Yatzkan, H.S. Judelson, Multiple pathways regulate the induction of genes during zoosporogenesis in Phytophthora infestans, Mol. Plant-Microbe Interact. 17 (2004) 330-337.

[52] A.G. McLoughlin, N.Wytinck, P.L. Walker, I.J. Girard, K.Y. Rashid, T. De Kievit, W.G.D Fernando, S. Whyard, M.F. Belmonte, Identification and application of exogenous dsRNA confers plant protection against Sclerotinia sclerotiorum and Botrytis cinerea, Scientific Reports 8 (2018) 7320 .

[53] M. Wang, N. Thomas, Hailing Jin, Cross-kingdom RNA trafficking and environmental RNAi for powerful innovative pre- and post-harvest plant protection, Current Opinion in Plant Biol. 38 (2007) 133-141.

[54] A. Dalakouras, W. Jarausch, G. Buchholz, A. Bassler, M. Braun, T. Manthey, G. Krczal, M. Wassenegger, Delivery of hairpin RNAs and small RNAs into woody and herbaceous plants by trunk injection and petiole absorption, Frontiers in Plant Sci. 9 (2018) 1253.

[55] A. Dalakouras, M. Wassenegger, J.N. McMillan, V. Cardoza, I. Maegele, E. Dadami, M. Runne, G. Krczal, M. Wassenegger, Induction of silencing in plants by high-pressure spraying of In vitro-synthesized small RNAs, Frontiers in Plant Sci., 7 (2016)1327.

[56] Flavia Pampolini, Thais B. Rodrigues, Ramya S. Leelesh, Tomokazu Kawashima, Lynne K. Rieske, Confocal microscopy provides visual evidence and confirms the feasibility of dsRNA delivery to emerald ash borer through plant tissues, J. Pest Science, 93 (2020)1143-1153

[57] K.S. Kim, H.S. Judelson, Sporangium-Specific Gene Expression in the Oomycete Phytopathogen Phytophthora infestans, Eukaryotic Cell 2 (2003) 1376-1385.

[58] B.N. Adhikari, J.P. Hamilton, M.M. Zerillo, N. Tisserat, C.A. Lévesque, C.R. Buell, Comparative Genomics Reveals Insight into Virulence Strategies of Plant Pathogenic Oomycetes, PLoS ONE, 8 (2006) e 75072-10. doi.org/10.1371/journal.pone.0075072 
[59] L.L. Hoyer, The ALS gene family of Candida albicans, Trends in Microbiol. 9 (2001) 176180.

[60] F.M. Klis, P. De Groot, K. Hellingwerf, Molecular organization of the cell wall of Candida albicans, Medical Mycology Supplement 39 (2001) 1-8.

[61] J.W. Van't Klooster, G. Van Den Berg-Velthuis, P. Van West, F. Govers, tef1, a Phytophthora infestans gene encoding translation elongation factor $1 \alpha$, Gene 249 (2000) 145-151.

[62] McLoughlin AG, Wytinck N, Walker PL, Girard IJ, Rashid KY, De Kievit T, Fernando WGD, Whyard S, Belmonte MF. 2018. Identification and application of exogenous dsRNA confers plant protection against Sclerotinia sclerotiorum and Botrytis cinerea. Scientific Reports 8: 7320.

[63] M. Wang, A.Weiberg, F.M. Lin, B.P.H.J. Thomma, H. Huang Da, H. Jin, Bidirectional crosskingdom RNAi and fungal uptake of external RNAs confer plant protection, Nature Plants 2 (2016) 16151. doi.org/10.1038/nplants.2016.151

[64] X.S. Song, K.X. Gu, X.X. Duan, X.M. Xiao, Y.P. Hou, Y. Duan, J.X. Wang, Na Yu, M.G. Zhou, Secondary amplification of siRNA machinery limits the application of spray-induced gene silencing, Mol. Plant Pathol. 19 (2018) 2543-2560.

[65] M, Wang, N. Thomas, Hailing Jin, Cross-kingdom RNA trafficking and environmental RNAi for powerful innovative pre- and post-harvest plant protection, Current Opinion in Plant Biol. 38 (2017) 133-141.

[66] M.Wang, H. Jin, Spray-Induced Gene Silencing: a Powerful Innovative Strategy for Crop Protection, Trends in Microbiol. 25 (2017) 4-6.

[67] A. Weiberg, M. Wang, F.M. Lin, H. Zhao, Z. Zhang, I. Kaloshian, H. Huang Da, H. Jin, Fungal small RNAs suppress plant immunity by hijacking host RNA interference pathways, Science 342 (2013) 118-123.

[68] S.C. Whisson, A.O. Avrova, P. Van West, J.T. Jones, A method for double-stranded RNAmediated transient gene silencing in Phytophthora infestans. Mol. Plant Pathol. 6 (2005) 153-163.

[69] Q. Cai, L. Qiao, M. Wang, B. He, F.M. Lin, J. Palmquist, S. Huang Da, H. Jin, Plants send small RNAs in extracellular vesicles to fungal pathogen to silence virulence genes. Science 360 (2018) 1126-1129.

[70] S. Wang, L. Welsh, P. Thorpe, S.C. Whisson, P.C. Boevink, P.R.J. Birch, The Phytophthora infestans haustorium is a site for secretion of diverse classes of infection-associated proteins. mBio 9 (2018) e01216-18.

[71] C.O. Micali, U. Neumann, D. Grunewald, R. Panstruga, R. O’Connell, Biogenesis of a specialized plant-fungal interface during host cell internalization of Golovinomyces orontii haustoria. Cellular Microbiol. 13 (2011) 210-226.

[72] Q. Cai, L. Qiao, M. Wang, B. He, F.M. Lin, J. Palmquist, S. Huang Da, H. Jin, Plants send small RNAs in extracellular vesicles to fungal pathogen to silence virulence genes. Science 360 (2018) 1126-1129. 
[73] C. Yin, J.E. Jurgenson, S.H. Hulbert, Development of a host-induced RNAi system in the wheat stripe rust fungus Puccinia striiformis f. sp. tritici. Molecular Plant-Microbe Interactions 24 (2011) 554-561.

[74] V. Panwar, B. McCallum, G. Bakkeren, Host-induced gene silencing of wheat leaf rust fungus Puccinia triticina pathogenicity genes mediated by the Barley stripe mosaic virus. Plant Mol. Biol. 81 (2013) 595-608. 